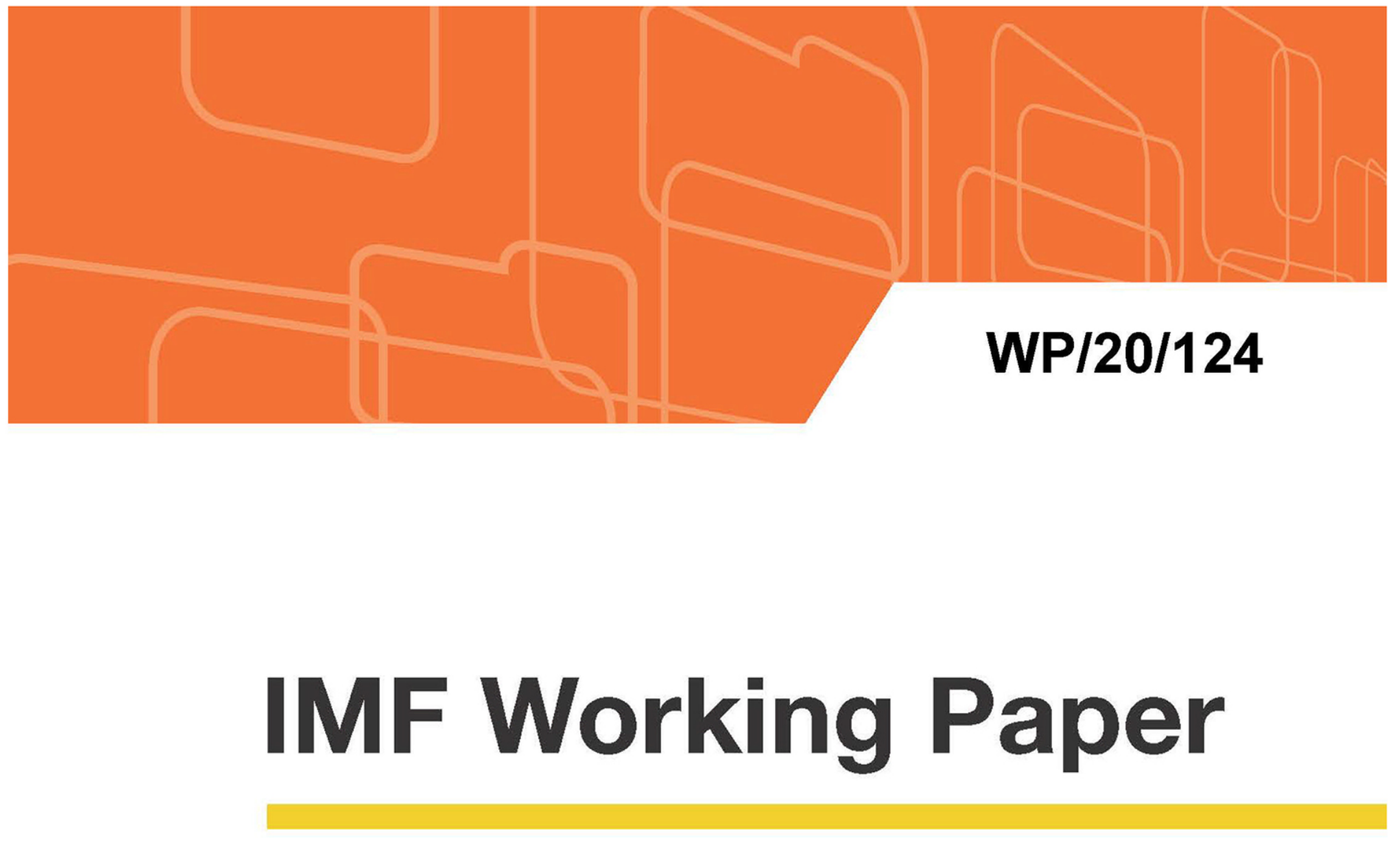

\title{
Reexamining the National Savings-Investment Nexus Across Time and Countries
}

by Antonio C. David, Carlos Eduardo Gonçalves, and Alejandro Werner

IMF Working Papers describe research in progress by the author(s) and are published to elicit comments and to encourage debate. The views expressed in IMF Working Papers are those of the author(s) and do not necessarily represent the views of the IMF, its Executive Board, or IMF management. 


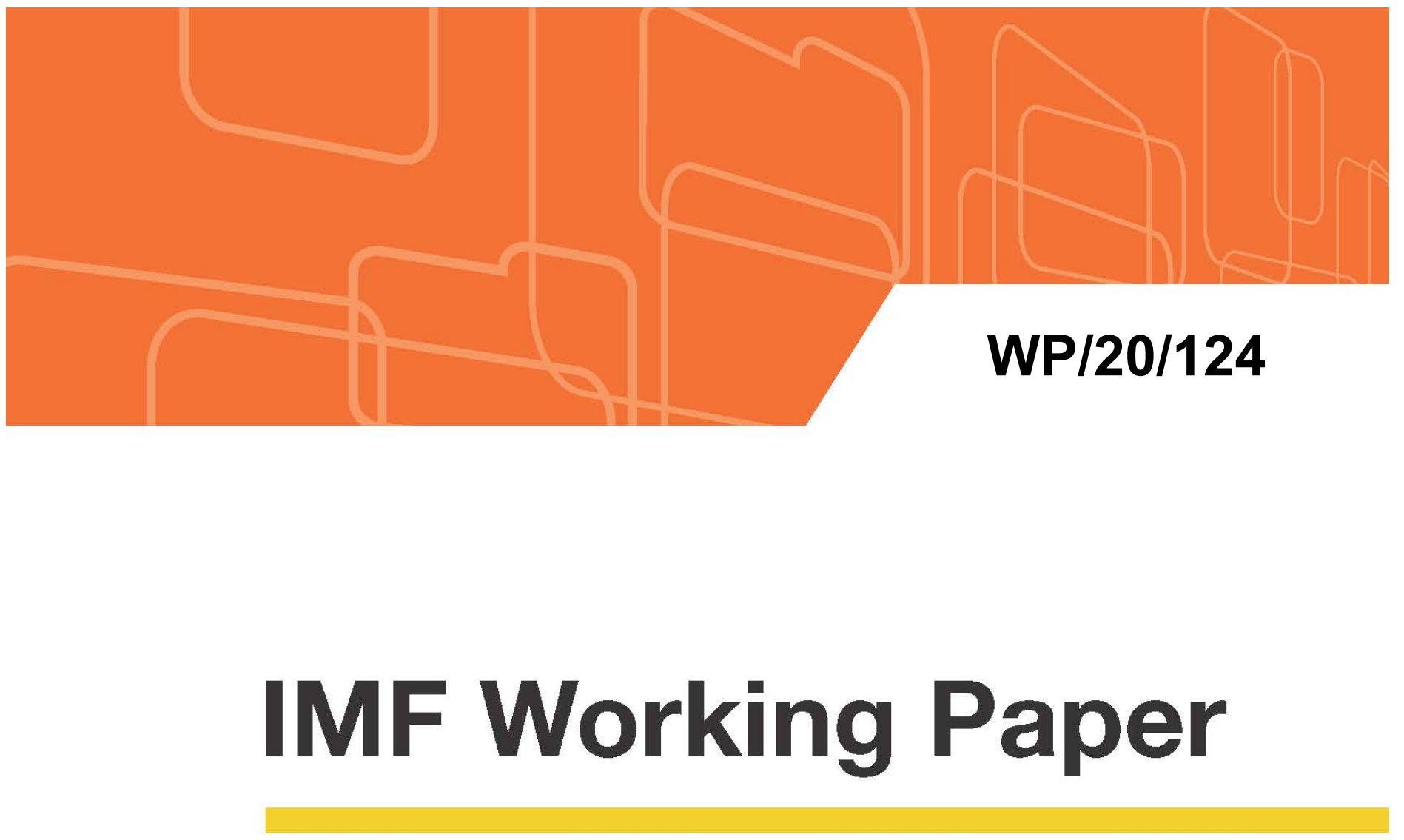

\section{Reexamining the National Savings-Investment Nexus Across Time and Countries}

by Antonio C. David, Carlos Eduardo Gonçalves, and Alejandro Werner

IMF Working Papers describe research in progress by the author(s) and are published to elicit comments and to encourage debate. The views expressed in IMF Working Papers are those of the author(s) and do not necessarily represent the views of the IMF, its Executive Board, or IMF management. 


\title{
IMF Working Paper
}

Western Hemisphere Department

\author{
Reexamining the National Savings-Investment Nexus Across Time and Countries ${ }^{1}$ \\ Prepared by Antonio C. David, Carlos Eduardo Gonçalves, and Alejandro Werner \\ Authorized for distribution by Jorge Roldos
}

July 2020

\begin{abstract}
IMF Working Papers describe research in progress by the author(s) and are published to elicit comments and to encourage debate. The views expressed in IMF Working Papers are those of the author(s) and do not necessarily represent the views of the IMF, its Executive Board, or IMF management.
\end{abstract}

\begin{abstract}
Domestic savings and investment are positively correlated across countries and through time, as Feldstein-Horioka (FH) unveiled 40 years ago. We argue that an interpretation of this correlation based on market failures is more consistent with data patterns than alternative hypotheses. Moreover, resorting to instrumental variables techniques, we conclude that the relationship is causal: an exogenous rise in savings increases investment. This result holds in the full sample of countries and for emerging and developing economies, but there is evidence that the positive association in advanced economies is due to endogeneity bias. The core of our identification strategy relies on the idea that population age structure influences savings, but not total investment directly. Specifically, we use the share of adults in the [35-49] years of age bracket as an instrument for savings. Our estimates pass weak-instruments robust inference.

JEL Classification Numbers: E21; E22; F40

Keywords: Feldstein-Horioka Puzzle, Investment, Savings, Causality.

Author's E-Mail Address: adavid@imf.org, cgoncalves@imf.org, awerner@imf.org
\end{abstract}

\footnotetext{
${ }^{1}$ Genevieve Lindow and Juan Pablo Cuesta provided outstanding research assistance. We would like to thank Marcos Chamon, Ana Ivanova, Nicolas Magud, and Jorge Roldos for very useful comments. All usual disclaimers apply.
} 


\section{Introduction}

The Feldstein-Horioka (FH) puzzle establishing a strong positive correlation between domestic savings and investment rates stood the test of time (Feldstein and Horioka, 1980). In this paper, we argue that this correlation has a causal interpretation. Essentially, the robustness of the FH link across time and country groups contradicts the small open economy neoclassical model featuring consumption smoothing and an exogenous global interest rate.

We begin by arguing that an interpretation of the $\mathrm{FH}$ correlation based on financial market failures is consistent with the patterns observed in the data. In the presence of such failures, the FH correlation should be higher for emerging markets than advanced economies, where credit market failures are less pronounced (Coeurdacier, Guibaud, and Jin, 2015). Also this correlation is expected to fall in good times and increase in bad times, since adverse selection problems are less acute during the former. These patterns are borne out by the data.

Traditionally, the presence of policy-imposed restrictions to international capital mobility has been advanced as a rationale for the puzzle. But during the last four decades or so other explanations have been proposed (see Aspergis and Tsoumas, 2009; and Singh, 2016 for comprehensive surveys of the literature). Baxter and Crucini (1993) show that even in a stochastic growth model with perfect capital mobility, national saving and investment rates are positively correlated if technology shocks in large countries have non-trivial effects on world interest rates. Global productivity shocks (common across countries) are also put forward as a possible explanation for the puzzle: driving the co-movement between savings and investment rates (Glick and Rogoff, 1995). Barro, Mankiw, and Sala-i-Martin (1995) point to differences in tax rates, broadly interpreted as distortions to the returns on physical and human capital, as an explanation for the puzzle. The underlying idea is simple: in a standard growth model with full capital mobility, foreign savings might not respond to changes in differential returns if after-tax returns on capital are equalized via tax policy. Obstfeld and Rogoff (2000) highlight the role of international trading costs in explaining the observed correlation in the data.

In our view, none of these theories appear to be well-suited to explain the changes in the FH correlation across countries and through time. The evidence we present supports instead an explanation based on failures in international capital markets. Bai and Zhang (2010), for example, argue that the puzzle can be explained by two types of financial frictions in a general equilibrium model: limited enforcement (low default penalties) and limited spanning (the only asset available is a non-contingent bond). The puzzle is solved when one considers the combination of these frictions, which lead to lower levels of capital flows relative to the

CInternational Monetary Fund. Not for Redistribution 
frictionless model.

The second and most important contribution of the paper is to tackle the issue of causality. The vast literature on the FH puzzle is to a large extent agnostic when it comes to establishing causality: do domestic savings cause investment? To differentiate correlation from causality, we resort to instrumental variables (IV) techniques both in panel and pooled cross-section settings.

In terms of identification strategy, we use population structure as an instrument for savings. In essence, country-period pairs featuring larger shares of adults in the [35:49] age bracket display higher domestic savings. This empirical regularity is in line with the life-cycle hypothesis stating that children, adults at the initial rungs of the salary ladder and the elderly lack either the ability or a reason to save (Grigoli, F., Herman, A., and Schmidt-Hebbel, K. 2018).

As far as the exclusion restriction is concerned, we argue that the share of adults in a particular age brackets should not matter for total investment rates through channels other than savings. As suggested by the Directed Technological Change literature (Acemoglu, 2015 and Acemoglu and Restrepo, 2017), the relative scarcity/abundance of certain factors of production should affect the composition of investment, but not necessarily its share of GDP. That is at the core of our identification strategy.

The IV estimates obtained across different specifications are statistically significant for the whole sample of countries and for the sample of emerging economies pointing to a causal relationship between domestic savings and investment. Moreover, they are larger than OLS estimates suggesting the presence of measurement error. However, the coefficient on domestic savings is not significant for the sample of advanced economies in line with the explanations of the puzzle based on market failures.

Recent contributions have used panel co-integration methods and granger causality tests focusing on certain groups of countries to re-examine the relationship between domestic savings and investment (Cavallo and Pedemonte, 2015; Irandoust, 2019). Dooley, Frankel and Mathieson (1987) is the only paper we are aware of that uses an IV approach. They also resort to population shares (albeit a different one from ours) as an instrument for savings, but explore only the cross-section dimension using a much smaller set of countries. Their results stand in stark contrast to our findings, however. First, their OLS estimates are higher for the group of developed economies. Moreover, none of their IV estimates are statistically significant. In sum, these findings suggest that correlation does not mean causation in the case of the Feldstein-Horioka puzzle, while we reach the opposite conclusion.

Following this introduction, the paper is structured as follows. Section 2 provides a brief overview of the data used in the analysis. Subsequently, we examine simple national 
saving-investment scatter plots and correlations from a cross-sectional perspective and across countries and time. Moreover, we also present regressions controlling for a parsimonious set of additional potential determinants of investment and perform a number of robustness checks confirming that the FH correlation holds. In Section 4, we tackle the causality question using instrumental variables, both for panel and the pooled cross-section. Finally, Section 5 concludes and discusses some policy implications.

\section{A Brief Overview of Data Sources}

We rely on three data sources for the main variables of interest, namely savings and investment rates (expressed as a share of GDP): i) the IMF's World Economic Outlook (WEO) Database; ii) the World Development Indicators (WDI) database from the World Bank; and iii) the Penn World Tables (PWT) version 9.1 (Feenstra et al., 2015). While the WEO and WDI datasets already contain a gross national saving variable, in the case of PWT data, we construct the savings rate variable from shares of other income components in line with Horioka and Terada-Hagiwara (2011), such that: $s=S / G D P=1-c s h_{c}-c s h_{g}$, where $c s h_{c}$ is share of household consumption and $c s h_{g}$ is the share of government consumption. Moreover, the WEO database contains information on private savings and investment rates that is not available in the other datasets.

We exclude countries with a population of less than one million persons in 2015 from the sample of countries considered. For most specifications we also exclude 15 countries that are heavily reliant on oil exports, because it is likely that they present an atypical link between domestic savings and investment, however some robustness checks do include these economies. ${ }^{1}$ We also exclude observations that present negative savings rates as well as investment rates above 100 percent of GDP. Data coverage over the time series and cross-country dimension varies significantly depending on the database. Since we are more interested in patterns that purge the effects that occur at a the business cycle frequency, our analysis is done using variables averaged by 5-year non-overlapping periods. Therefore, our time dimension is comprised of 9 periods starting in the 1970s when we use the PWT variables, but is reduced to 5 periods when variables from WDI and WEO are used as data availability for these databases starts in the 1990s.

In addition to savings and investment rates data, we employ several control variables and instruments in the specifications discussed throughout the paper. Appendix A provides a more detailed description of data and sources. We rely on the PWT database for data on

\footnotetext{
${ }^{1}$ The list of these oil-exporting countries is the following: Angola, United Arab Emirates, Azerbaijan, Republic of Congo, Equatorial Guinea, Iran, Iraq, Kuwait, Libya, Oman, Qatar, Saudi Arabia, South Sudan, Timor-Leste and Venezuela.
} 
GDP per capita and the relative price of investment. Moreover, to capture capital account restrictions, we use the index of de jure capital account openness constructed by Chinn and Ito (2006) based on information from the IMF's Annual Report on Exchange Arrangements and Exchange Restrictions (AREAER). Higher levels of the index point to a more open capital account. We also consider regressions that control for commodity terms of trade (Gruss, 2014) and banking, currency, and sovereign debt crises dates (Laeven and Valencia, 2018).

Moreover, to capture expropriation risk, we use the variable measuring constraints on executive power from the Polity IV database, which aims to capture checks and balances between the various parts of the decision-making process. For the instrumental variables section, we use information on the population age-structure from the WDI database and also data on colonial origins from Acemoglu, Johnson, and Robinson (2001) in some specifications.

\section{Saving-Investment Correlations}

In this section we slice and dice the data to convey two basic messages: (i) the FH correlation is robust and (ii) its heterogeneity across time and country groups is consistent with an explanation based on financial market failures: the correlation decreases during good times relative to more turbulent periods and is weaker for more developed economies.

\subsection{Cross-sectional evidence}

All panels of Figure 1 show a strong positive association between investment rates and national savings rates across the different datasets considered (each point represents a country-period pair), which holds over the longer 1970-2015 period and also for more recent periods (1990-2015). Importantly, the positive correlation continues to hold when we use WEO data containing only private flows of investment and savings (Figure 2). 
Figure 1: Savings and Investment, All Countries
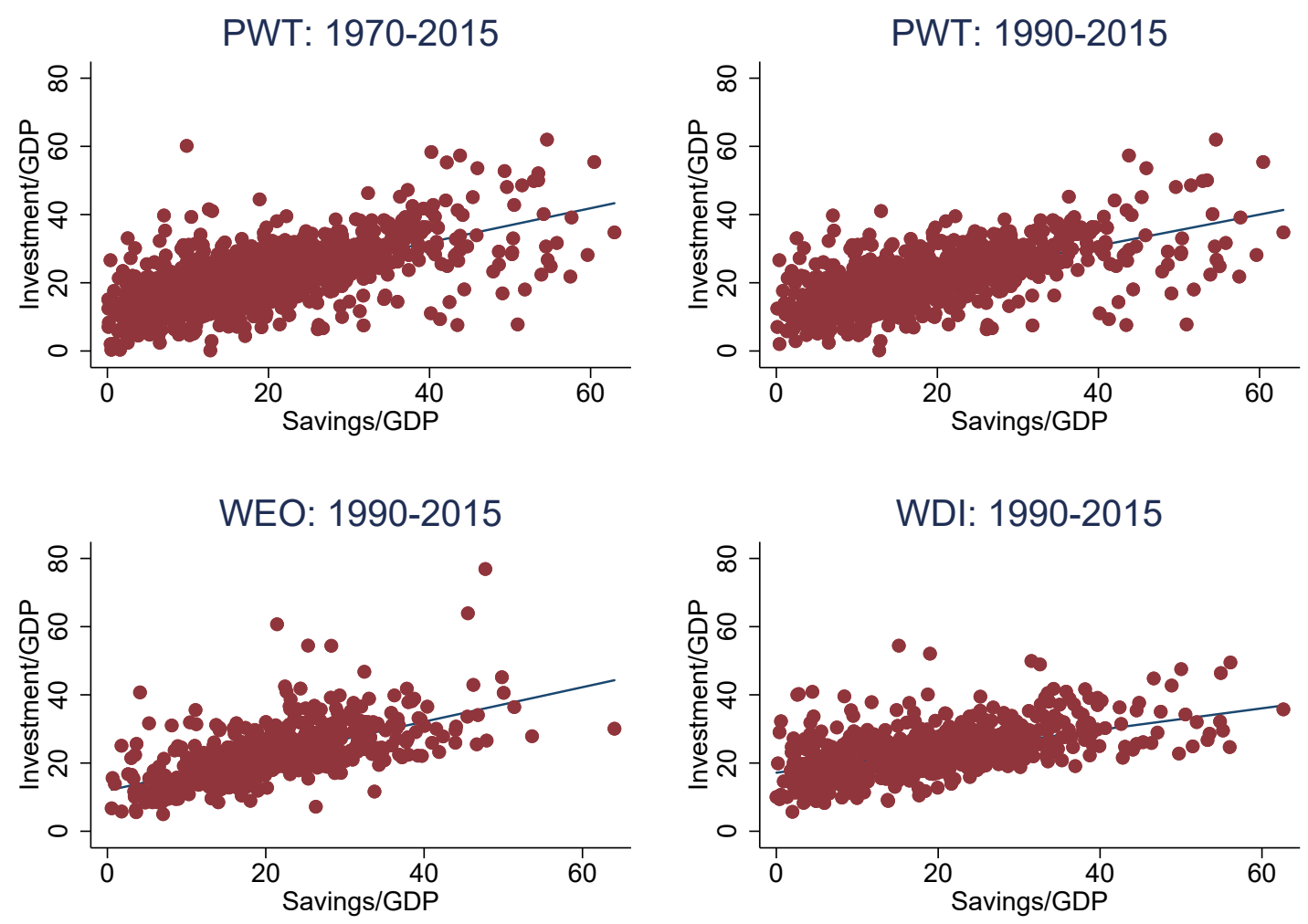
Figure 2: Private Flows Only (WEO)

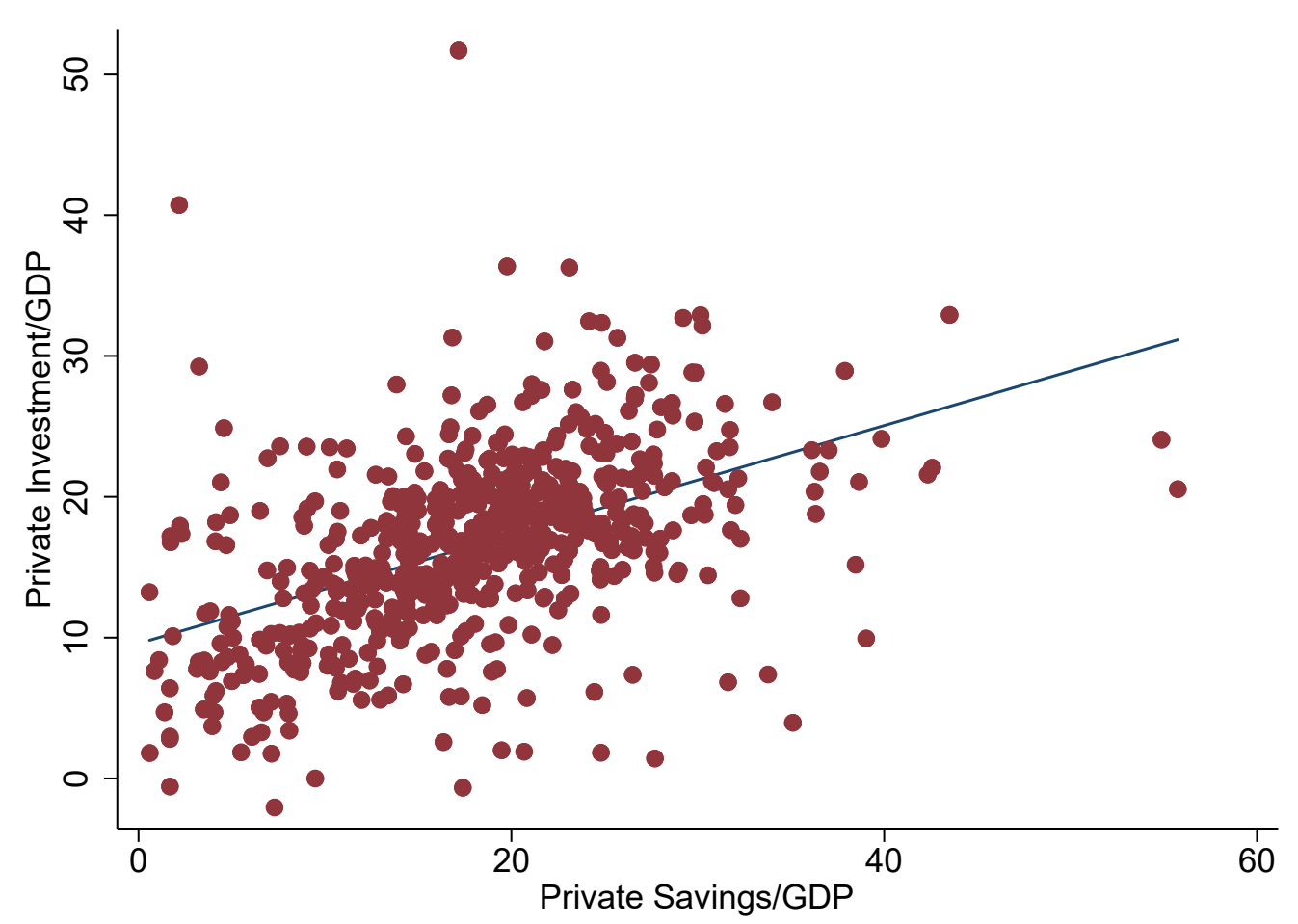

Moreover, Figures 3 and 4 illustrate that the strong and positive correlation also holds across different income groups (AEs, EMs, and LICs) and that its size is inversely associated with the level of economic development. While Figure 3 depicts simple scatter plots, the numbers shown in the Figure 4 are the coefficients of panel-regressions of investment on savings controlling for time and country fixed effects for each group of countries. Since credit market failures are arguably more pronounced in less developed economies (see Coeurdacier, Guibaud, and Jin, 2015 for a model in which credit constraints are more severe in less developed countries leading to divergent savings behavior relative to AEs), we would expect the correlation between national savings and investment rates to be higher in these economies. 
Figure 3: Savings and Investment across Income Groups
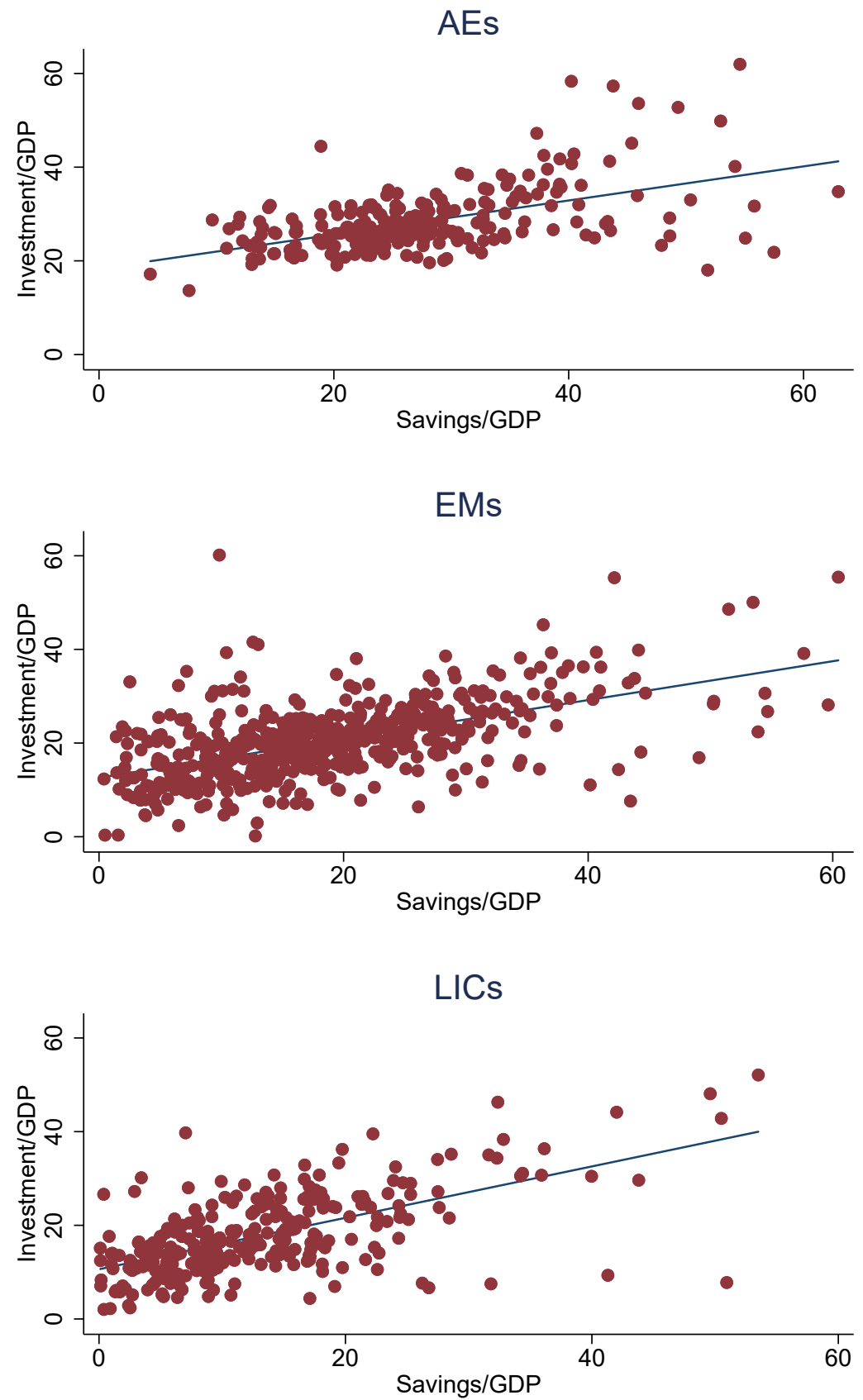
Figure 4: Savings and Investment Correlation across Income Groups

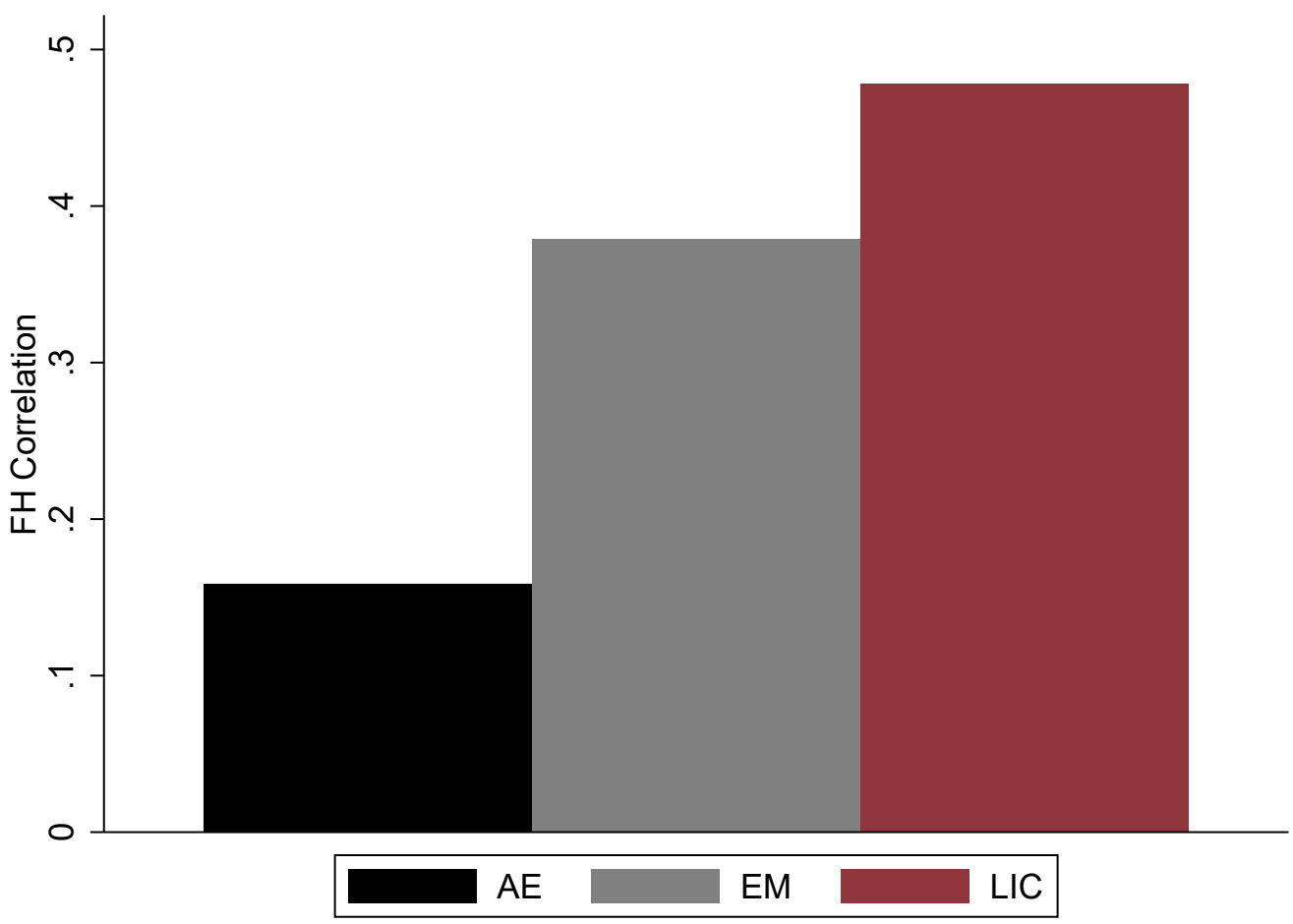

\subsection{Correlations across time}

Frictions preventing the smooth functioning of credit markets are more binding during turbulent times. Adverse selection, in particular, becomes more relevant since good credit risks usually refrain from issuing debt when interest rates and risk are high. This is arguably even more acute when it comes to cross-borders flows. Hence, in bad times one should expect domestic investment not only to be lower, but also more tightly correlated with domestic savings. The opposite should hold for good times: lower overall risk aversion pushing the correlation between domestic savings and investment towards lower levels.

Figure 5 is consistent with this reasoning. The correlation stands at over 0.5 during the financially turbulent years of the 1980s and 1990s. It then falls precipitously to 0.3 during the so-called "Great Moderation", increasing again after the Global Financial Crisis (GFC). Moreover, as Figure 6 shows, even though there are clear level differences when we compare the IMF-WEO and WB-WDI datasets, the time-variation pattern remains broadly similar to the one presented using PWT data in Figure 5. 
Figure 5: Savings and Investment Correlation across Time

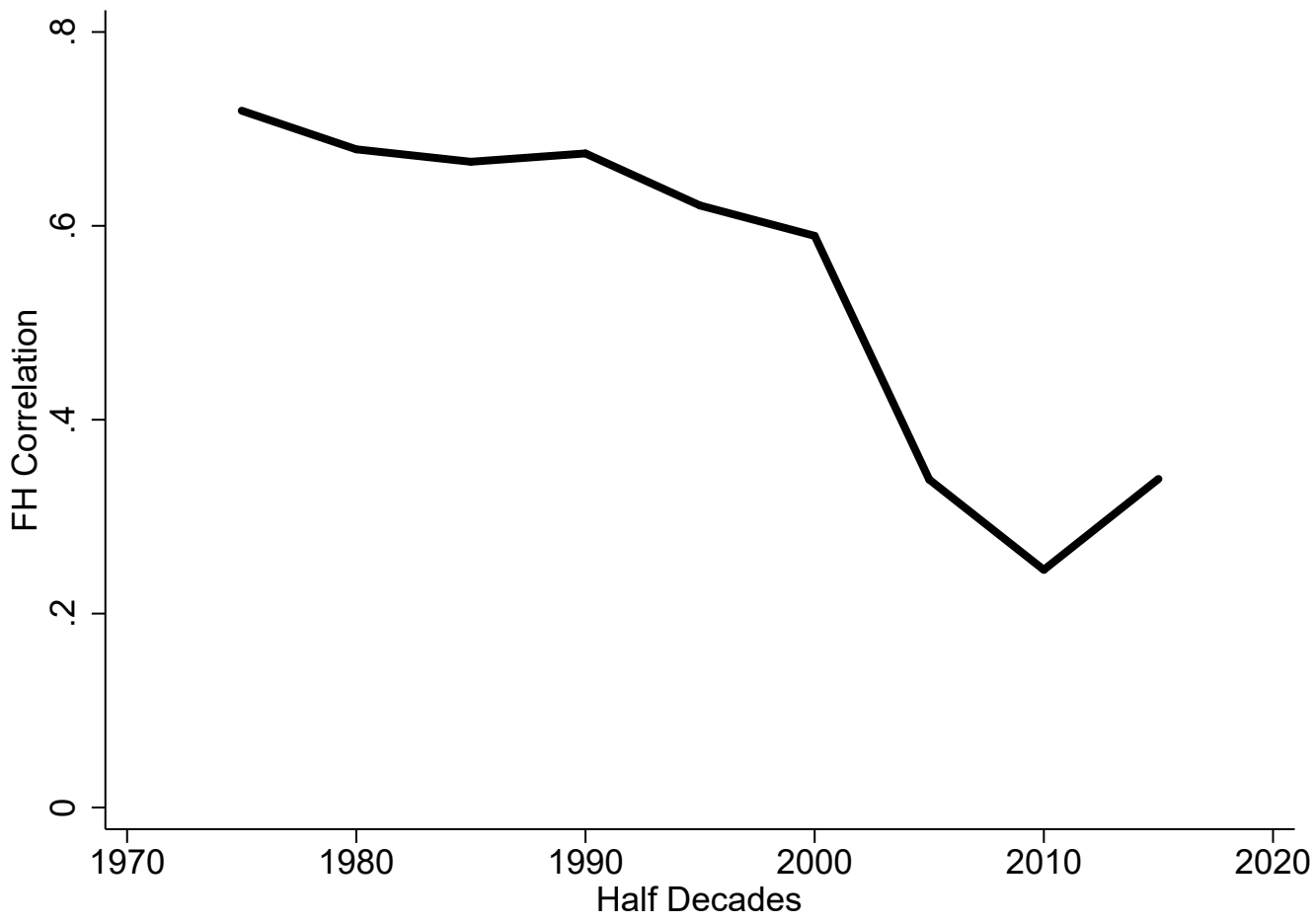

Figure 6: Savings and Investment Correlation across Datasets

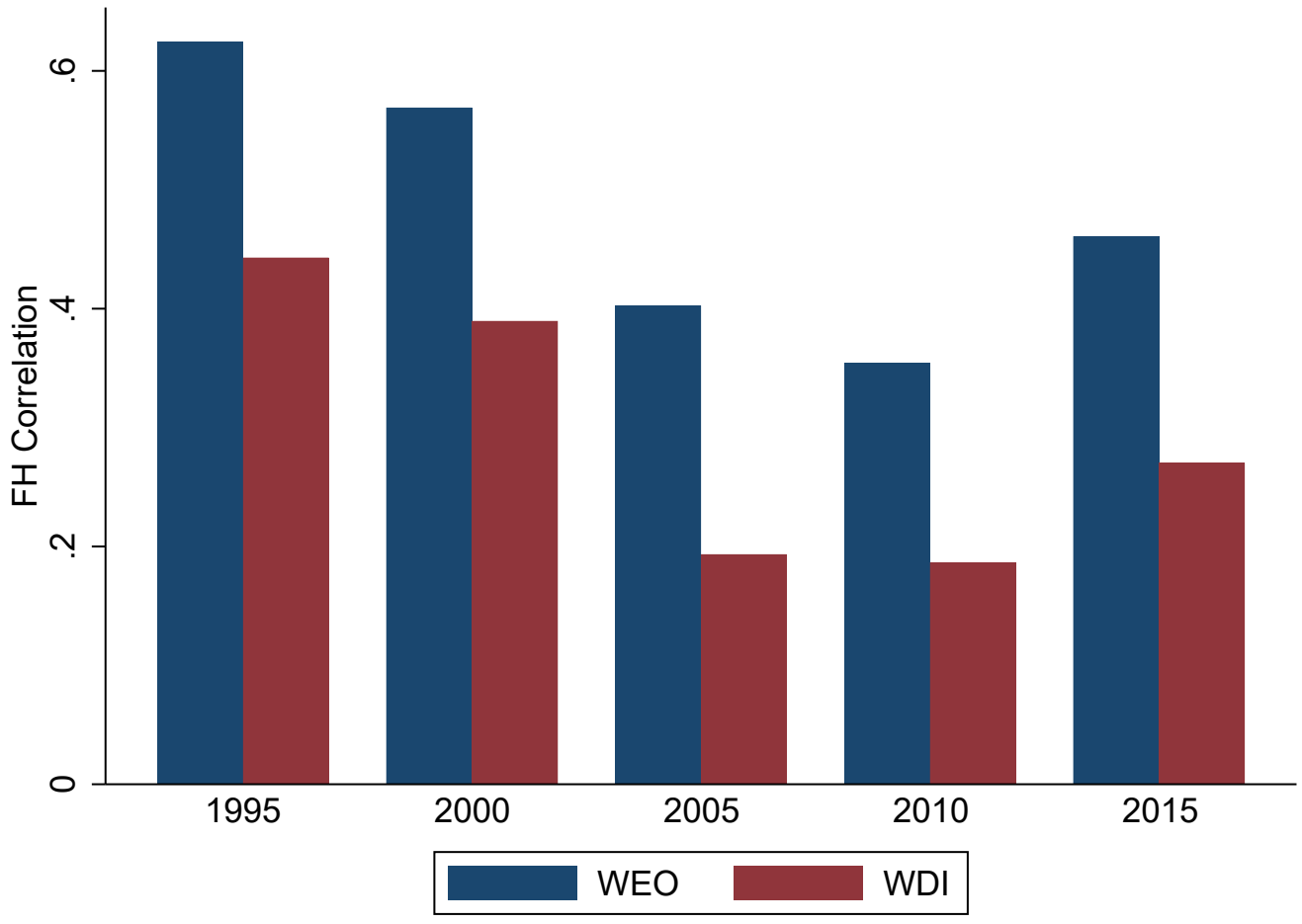




\subsection{Benchmark regressions}

In this section, we present the results from parsimonious Pooled and Fixed-Effects OLS regressions of investment rates on national savings, controlling for time-effects, a protection of property rights indicator (constraints on the power of the executive) and initial GDP per capita. The latter variable is aimed at capturing convergence forces and the proxy for property rights protection captures the private appropriability of investment returns.

We begin by discussing the results based on PWT data (Table 1). For comparison purposes, we also present a specification (specification 1) that tries to replicate the original Feldstein and Horioka (1980) regressions by considering the same set of countries and a similar time period. The savings-investment correlation is estimated with high precision for the full sample as well as in the two groups of countries considered (advanced economies as well as emerging and developing countries i.e. Non-AE).

In our preferred specification - Fixed-Effects and Full Sample, the coefficient for initial GDP per capita is statistically significant and negative, hinting at convergence forces (diminishing returns to capital). The variable capturing the protection of property rights also enters significantly and with the expected sign in the pooled OLS specification. ${ }^{2}$ Inter- $^{-}$ estingly, the size of the FH coefficient does not vary much across the different specifications, even if it is somewhat smaller in the case of the Advanced Economies sample and somewhat larger in the specification that replicates the original Feldstein-Horioka paper. ${ }^{3}$

These coefficient estimates are in line with the findings of Cavallo and Pedemonte (2015), who report a significant correlation between savings and investment rates of about 0.39 over the period 1980-2013 for LAC countries using panel co-integration techniques. These authors show that there is a fair amount of intra-regional heterogeneity and that the estimated correlation has been declining over time.

In addition, the positive and significant link between investment and domestic savings is confirmed using the WEO and WDI datasets on savings and investment rates (Table 2), but the evidence for smaller coefficients in AEs is less apparent. To be consistent with the time dimension of the WDI and WEO databases, we also reestimate the specifications using PWT data starting in 1990 and the results are in line with the ones reported previously.

\footnotetext{
${ }^{2}$ Since time variation for this variable is very small, we do not include it in the fixed-effects specifications.

${ }^{3}$ We also estimated specifications that exclude large AEs, namely the USA, Japan, Germany, France and the UK. The estimated coefficient of domestic savings remains virtually unchanged for both pooled OLS and fixed-effects specifications.
} 
Table 1: PWT 9.1 Data. Starting in 1970

\begin{tabular}{lccccc}
\hline & $(1)$ & $(2)$ & $(3)$ & $(4)$ & $(5)$ \\
& Pooled & Pooled & FE & FE & FE \\
& FH (1980) & Full & Full & AE & Non-AE \\
Controls & I/GDP & I/GDP & I/GDP & I/GDP & I/GDP \\
\hline & & & & & \\
Savings/GDP & $0.568^{* * *}$ & $0.489^{* * *}$ & $0.404^{* * *}$ & $0.338^{* * *}$ & $0.403^{* * *}$ \\
& $(0.122)$ & $(0.0322)$ & $(0.0528)$ & $(0.115)$ & $(0.0615)$ \\
Constraints on Executive & & $0.603^{* * *}$ & & & \\
& & $(0.126)$ & & & \\
Initial GDP & & $-1.07 \mathrm{e}-05$ & $-0.000424^{* * *}$ & $-0.000432^{* * *}$ & $-0.000208^{* *}$ \\
& & $(2.98 \mathrm{e}-05)$ & $(6.51 \mathrm{e}-05)$ & $(0.000113)$ & $(9.88 \mathrm{e}-05)$ \\
\hline Fixed Effects & $\mathrm{N}$ & $\mathrm{N}$ & $\mathrm{Y}$ & $\mathrm{Y}$ & $\mathrm{Y}$ \\
Time-Effects & $\mathrm{N}$ & $\mathrm{Y}$ & $\mathrm{Y}$ & $\mathrm{Y}$ & $\mathrm{Y}$ \\
\hline Observations & 39 & 916 & 916 & 223 & 693 \\
R-squared & 0.421 & 0.458 & 0.349 & 0.416 & 0.357 \\
Number of id & & & 136 & 28 & 108 \\
\hline
\end{tabular}

Robust standard errors in parentheses. ${ }^{* * *} \mathrm{p}<0.01,{ }^{* *} \mathrm{p}<0.05,{ }^{*} \mathrm{p}<0.1$

\subsection{Extensions}

As a first extension exercise, we add the following explanatory variables to the benchmark regressions: (i) the relative price of investment, (ii) an index of capital account openness, and (iii) crises dates (including banking, currency, and sovereign debt crises). The relative price of investment (the ratio of the price of investment to the price of consumption) is an important driver of investment rates in a very intuitive sense, as ceteris paribus a decline in this relative price would increase incentives to invest (Lian et al., 2019), but it also captures policy distortions creating wedges that end up affecting investment decisions. The index of de jure capital account openness captures the role of policy-imposed restrictions on capital mobility that would prevent foreign savings from financing domestic investment. It would then break the workings of market mechanisms present in the standard neoclassical growth model that allow for consumption smoothing (that is, a reduction in the correlation between national savings and investment rates). The inclusion of crises dates is also intuitive as these events could affect investment rates directly through disruptions in credit markets and/or have an impact on the link between investment and domestic savings. We focus on protracted crises in the regressions presented, which are defined as crises lasting more than one year. However, we obtain similar results when all crises dates are considered.

Table 3 presents the results of different specifications including these additional control variables as well as interaction terms with the domestic savings rate. The savings coefficient 
Table 2: WEO, WDI and PWT Data. Starting in 1990

\begin{tabular}{|c|c|c|c|c|}
\hline & $\begin{array}{c}(1) \\
\text { Pooled } \\
\text { Full } \\
\text { I/GDP } \\
\text { WEO }\end{array}$ & $\begin{array}{c}(2) \\
\text { FE } \\
\text { Full } \\
\text { I/GDP } \\
\text { WEO }\end{array}$ & $\begin{array}{c}(3) \\
\mathrm{FE} \\
\mathrm{AE} \\
\mathrm{I} / \mathrm{GDP} \\
\mathrm{WEO}\end{array}$ & $\begin{array}{c}(4) \\
\text { FE } \\
\text { Non-AE } \\
\text { I/GDP } \\
\text { WEO }\end{array}$ \\
\hline Savings/GDP & $\begin{array}{c}0.572^{* * *} \\
(0.0489)\end{array}$ & $\begin{array}{c}0.565^{* * *} \\
(0.130)\end{array}$ & $\begin{array}{c}0.396^{* * *} \\
(0.0911)\end{array}$ & $\begin{array}{c}0.563^{* * *} \\
(0.150)\end{array}$ \\
\hline Constraints on Executive & $\begin{array}{c}0.314^{* *} \\
(0.149)\end{array}$ & & & \\
\hline Initial GDP & $\begin{array}{c}-0.000114^{* * *} \\
(2.47 \mathrm{e}-05)\end{array}$ & $\begin{array}{l}-0.000162 \\
(0.000110)\end{array}$ & $\begin{array}{c}-2.15 \mathrm{e}-05 \\
(0.000172)\end{array}$ & $\begin{array}{c}-3.92 \mathrm{e}-05 \\
(0.000227)\end{array}$ \\
\hline Fixed Effects & $\mathrm{N}$ & $\mathrm{Y}$ & $\mathrm{N}$ & $\mathrm{Y}$ \\
\hline Time-Effects & $\mathrm{Y}$ & $\mathrm{Y}$ & $\mathrm{Y}$ & $\mathrm{Y}$ \\
\hline Observations & 542 & 542 & 132 & 410 \\
\hline R-squared & 0.447 & 0.283 & 0.385 & 0.291 \\
\hline Number of id & & 120 & 27 & 93 \\
\hline & WDI & WDI & WDI & WDI \\
\hline Savings/GDP & $\begin{array}{c}0.381^{* * *} \\
(0.0325)\end{array}$ & $\begin{array}{c}0.491^{* * *} \\
(0.0874)\end{array}$ & $\begin{array}{c}0.555^{* * *} \\
(0.135)\end{array}$ & $\begin{array}{c}0.464^{* * *} \\
(0.0987)\end{array}$ \\
\hline Constraints on Executive & $\begin{array}{c}0.212 \\
(0.150)\end{array}$ & & & \\
\hline Initial GDP & $\begin{array}{c}-0.000145^{* * *} \\
(1.93 \mathrm{e}-05)\end{array}$ & $\begin{array}{c}-0.000396 * * * \\
(8.83 \mathrm{e}-05)\end{array}$ & $\begin{array}{l}-0.000115 \\
(0.000156)\end{array}$ & $\begin{array}{c}-0.000606^{* * *} \\
(0.000199)\end{array}$ \\
\hline Fixed Effects & $\mathrm{N}$ & $\mathrm{Y}$ & $\mathrm{N}$ & $\mathrm{Y}$ \\
\hline Time-Effects & $\mathrm{Y}$ & $\mathrm{Y}$ & $\mathrm{Y}$ & $\mathrm{Y}$ \\
\hline Observations & 521 & 521 & 132 & 389 \\
\hline R-squared & 0.345 & 0.325 & 0.391 & 0.352 \\
\hline Number of id & & 122 & 27 & 95 \\
\hline & PWT & $\mathrm{PWT}$ & PWT & $\mathrm{PWT}$ \\
\hline Savings/GDP & $\begin{array}{c}0.379^{* * *} \\
(0.0380)\end{array}$ & $\begin{array}{c}0.405^{* * *} \\
(0.0663)\end{array}$ & $\begin{array}{c}0.343^{* * *} \\
(0.122)\end{array}$ & $\begin{array}{c}0.360^{* * *} \\
(0.0751)\end{array}$ \\
\hline Constraints on Executive & $\begin{array}{c}0.668^{* * *} \\
(0.164)\end{array}$ & & & \\
\hline Initial GDP & $\begin{array}{c}1.45 \mathrm{e}-06 \\
(3.04 \mathrm{e}-05) \\
\end{array}$ & $\begin{array}{c}-0.000469^{* * *} \\
(8.06 \mathrm{e}-05)\end{array}$ & $\begin{array}{c}-0.000221 \\
(0.000179) \\
\end{array}$ & $\begin{array}{c}-0.000392^{* * *} \\
(0.000133)\end{array}$ \\
\hline Fixed Effects & $\mathrm{N}$ & $\mathrm{Y}$ & $\mathrm{Y}$ & $\mathrm{Y}$ \\
\hline Time-Effects & $\mathrm{Y}$ & $\mathrm{Y}$ & $\mathrm{Y}$ & $\mathrm{Y}$ \\
\hline Observations & 564 & 564 & 132 & 432 \\
\hline R-squared & 0.413 & 0.384 & 0.368 & 0.413 \\
\hline Number of id & & 132 & 27 & 105 \\
\hline
\end{tabular}


remains statistically significant in all specifications and its size is similar to the estimates presented previously. Similarly, the relative price of investment is always statistically highly significant and has the expected negative sign.

Table 3: Additional Control Variables

\begin{tabular}{|c|c|c|c|c|}
\hline Controls & $\begin{array}{c}(1) \\
\text { Pooled } \\
\text { Full } \\
\text { I/GDP }\end{array}$ & $\begin{array}{c}(2) \\
\text { FE } \\
\text { Full } \\
\text { I/GDP }\end{array}$ & $\begin{array}{c}(3) \\
\mathrm{FE} \\
\mathrm{AE} \\
\mathrm{I} / \mathrm{GDP}\end{array}$ & $\begin{array}{c}\text { (4) } \\
\text { FE } \\
\text { Non-AE } \\
\text { I/GDP }\end{array}$ \\
\hline Savings/GDP & $\begin{array}{c}0.444^{* * *} \\
(0.0495)\end{array}$ & $\begin{array}{c}0.515^{* * *} \\
(0.0605)\end{array}$ & $\begin{array}{c}0.568^{* * *} \\
(0.104)\end{array}$ & $\begin{array}{c}0.468^{* * *} \\
(0.0646)\end{array}$ \\
\hline Constraints on Executive & $\begin{array}{c}0.565^{* * *} \\
(0.164)\end{array}$ & & & \\
\hline Initial GDP & $\begin{array}{l}-3.72 \mathrm{e}-05 \\
(3.77 \mathrm{e}-05)\end{array}$ & $\begin{array}{c}-0.000442^{* * *} \\
(6.90 \mathrm{e}-05)\end{array}$ & $\begin{array}{l}-0.000174 \\
(0.000166)\end{array}$ & $\begin{array}{l}-0.000188 \\
(0.000177)\end{array}$ \\
\hline Inv. Price & $\begin{array}{c}-0.389^{* * *} \\
(0.131)\end{array}$ & $\begin{array}{c}-0.246^{* * *} \\
(0.0359)\end{array}$ & $\begin{array}{c}-8.317^{*} \\
(4.291)\end{array}$ & $\begin{array}{c}-0.238^{* * * *} \\
(0.0337)\end{array}$ \\
\hline Capital openness & $\begin{array}{c}3.039^{* *} \\
(1.305)\end{array}$ & $\begin{array}{l}2.867^{*} \\
(1.488)\end{array}$ & $\begin{array}{c}8.147^{* *} \\
(3.523)\end{array}$ & $\begin{array}{c}1.633 \\
(1.687)\end{array}$ \\
\hline Savings\#Openness & $\begin{array}{l}-0.0602 \\
(0.0734)\end{array}$ & $\begin{array}{l}-0.0765 \\
(0.0876)\end{array}$ & $\begin{array}{c}-0.300^{* *} \\
(0.140)\end{array}$ & $\begin{array}{c}-0.00886 \\
(0.122)\end{array}$ \\
\hline Crises & $\begin{array}{c}-4.437^{* *} \\
(1.760)\end{array}$ & $\begin{array}{l}-1.190 \\
(1.255)\end{array}$ & $\begin{array}{l}-0.144 \\
(5.127)\end{array}$ & $\begin{array}{l}-1.279 \\
(1.426)\end{array}$ \\
\hline Savings\#Crises & $\begin{array}{c}0.241^{* * *} \\
(0.0796)\end{array}$ & $\begin{array}{l}0.120 * * \\
(0.0585)\end{array}$ & $\begin{array}{l}0.0162 \\
(0.148)\end{array}$ & $\begin{array}{c}0.124 \\
(0.0831)\end{array}$ \\
\hline Fixed-Effects & $\mathrm{N}$ & $\mathrm{Y}$ & $\mathrm{Y}$ & $\mathrm{Y}$ \\
\hline Time-Effects & $\mathrm{Y}$ & $\mathrm{Y}$ & $\mathrm{Y}$ & $\mathrm{Y}$ \\
\hline Observations & 586 & 586 & 153 & 433 \\
\hline R-squared & 0.496 & 0.496 & 0.442 & 0.538 \\
\hline Number of id & & 119 & 27 & 92 \\
\hline
\end{tabular}

Controlling for crises dates does not seem to affect the results much. The coefficient for crises dates is negative as expected, but it is only statistically significant in the pooled regression specification. The interaction term between crises and the domestic savings coefficient is positive in all specifications, but it is not significant in the specifications that focus on different income groups. This indicates that the link between domestic savings and investment is stronger in periods of crises, but this is not robust to country sampling.

In addition, the index of de jure capital account openness enters significantly with a positive sign with the exception of the last specification focusing exclusively on non-advanced economies. This suggests that capital account openness seems to boost investment even 
after controlling for GDP per capita. The interaction term with the savings rate coefficient is negative, but not statistically significant for the full sample of countries, therefore there is little evidence that the more a country opens itself to capital flows, the weaker the connection between domestic savings and investment. ${ }^{4}$

Nonetheless, when we consider the split between different income groups, the interaction term between capital account openness and savings is significant for the sample of AEs. The negative value for the interaction term indicates that AEs with more open capital accounts tend to have a weaker link between domestic savings and investment. Figure 7 depicts the total marginal impact of domestic savings on investment for different values of the capital market openness variable. For AEs with high levels of capital account openness the total impact of domestic savings falls below 0.3 , while it exceeds 0.5 for AEs with lower levels of openness.

Figure 7: Final Impact of Savings in AEs

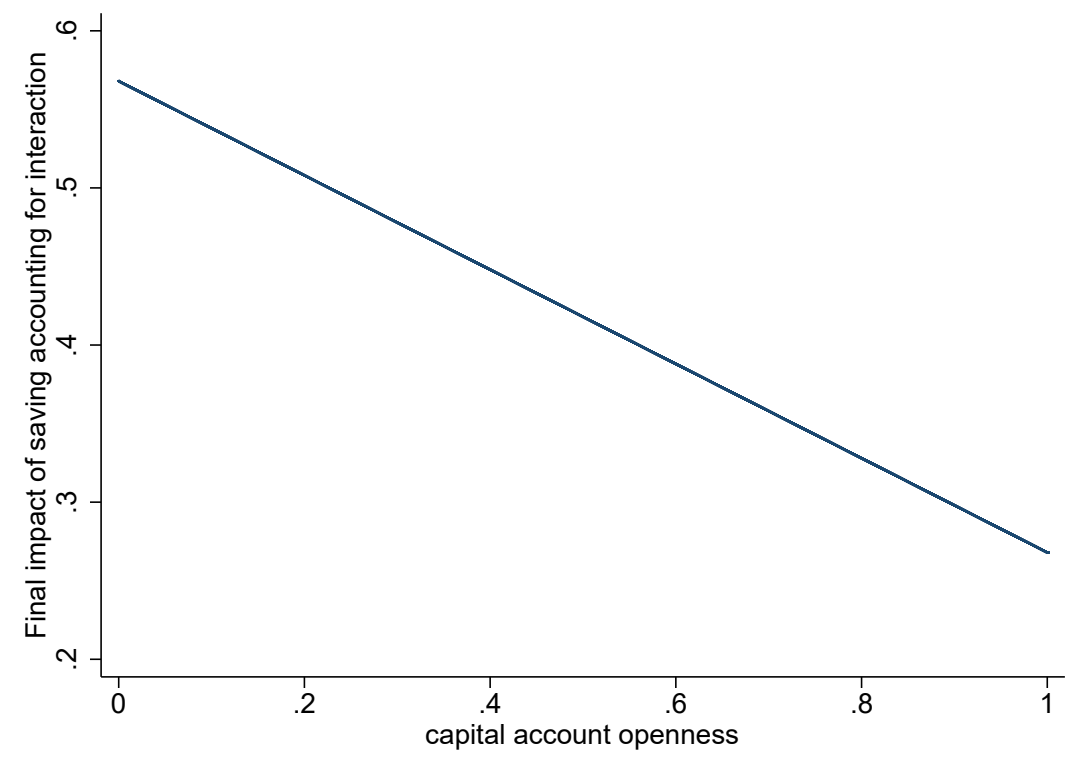

Moreover, we also estimate specifications controlling for a measure of financial sector development. A country's level of financial development could be an important determinant of investment rates because market imperfections and borrowing constraints can inhibit the accumulation of physical and human capital (Benhabib and Spiegel, 2000). We consider the broad-based financial development index proposed by Svirydzenka (2016). The index covers 183 countries on an annual frequency since 1980. It is composed of eight sub-indexes

\footnotetext{
${ }^{4}$ One should note that this finding does not necessarily contradicts our previous argument that failures in international capital markets may be an important explanation for the puzzle. The control variable used in this regressions in a de jure measure of policy-imposed restrictions on capital flows.
} 
that summarize how developed financial markets and financial institutions are along three dimensions (depth, access, and efficiency) using a large number of indicators. The results are reported in Appendix $\mathrm{C}$ and the evidence on the importance of the financial development index is mixed. The savings coefficient remains statistically significant and of similar magnitude to the ones reported above in all specifications.

Another extension consists in controlling for changes in terms of trade and comparing the results for countries that rely heavily on commodity exports (Table 4). ${ }^{5}$ Movements in commodity prices might be an important omitted variable, since in principle it should influence both investment and savings in the same direction. The coefficient on domestic savings falls somewhat when we focus on a sample of commodity exporting countries (Table 4 specifications 2 and 4), but the differences are economically small.

While commodity terms of trade growth does not enter the regressions in a significant manner, the interaction term between changes in terms of trade and the savings rate is negative and significantly different from zero (even if economically small). This indicates that increases in terms of trade modestly weaken the link between domestic savings and investment. ${ }^{6}$

In Figure 8 we revisit the evolution of the correlation between domestic savings and investment across time comparing the coefficient estimates for the case where no control variables are included (as in Figure 5) and a specification that includes GDP per capita, the relative price of investment, and the capital account openness index as control variables. One can note that the patterns are very similar and the control variables do not seem to affect much the association between savings and investment.

\footnotetext{
${ }^{5}$ Commodity exporters are defined as countries where the export share of oil, metals, and food on total exports is one standard deviation above the cross-country average. While we exclude oil exporters from the sample considered in most regressions in this paper (as discussed in previous sections) the specifications that focus on commodity exporters do include these countries.

${ }^{6}$ We also considered specifications that include deviations from trends rather than growth rates for the commodity terms of trade variable. The results are very similar to the ones reported here.
} 
Table 4: Commodity Prices and Commodity Exporters

\begin{tabular}{|c|c|c|c|c|}
\hline Controls & $\begin{array}{c}(1) \\
\text { Pooled } \\
\text { Full } \\
\text { I/GDP }\end{array}$ & $\begin{array}{c}(2) \\
\text { Pooled } \\
\text { Commodity Exp. } \\
\text { I/GDP }\end{array}$ & $\begin{array}{c}(3) \\
\text { FE } \\
\text { Full } \\
\text { I/GDP }\end{array}$ & $\begin{array}{c}\text { (4) } \\
\text { FE } \\
\text { Commodity Exp. } \\
\text { I/GDP }\end{array}$ \\
\hline Savings/GDP & $\begin{array}{c}0.474^{* * *} \\
(0.0439)\end{array}$ & $\begin{array}{c}0.267^{* * *} \\
(0.0782)\end{array}$ & $\begin{array}{c}0.536^{* * *} \\
(0.0576)\end{array}$ & $\begin{array}{c}0.450^{* * *} \\
(0.0653)\end{array}$ \\
\hline Constraints on Executive & $\begin{array}{c}0.630^{* * *} \\
(0.134)\end{array}$ & $\begin{array}{l}-0.220 \\
(0.195)\end{array}$ & & \\
\hline Initial GDP & $\begin{array}{c}6.28 \mathrm{e}-06 \\
(2.75 \mathrm{e}-05)\end{array}$ & $\begin{array}{c}1.31 \mathrm{e}-05 \\
(4.02 \mathrm{e}-05)\end{array}$ & $\begin{array}{c}-0.000219^{* *} \\
(8.61 \mathrm{e}-05)\end{array}$ & $\begin{array}{l}-7.53 \mathrm{e}-05 \\
(6.87 \mathrm{e}-05)\end{array}$ \\
\hline Inv. Price & $\begin{array}{c}-0.387^{* * *} \\
(0.129)\end{array}$ & $\begin{array}{c}-6.042^{* * *} \\
(1.224)\end{array}$ & $\begin{array}{c}-0.267^{* * *} \\
(0.0458)\end{array}$ & $\begin{array}{c}-6.665^{* * *} \\
(1.559)\end{array}$ \\
\hline Capital openness & $\begin{array}{c}4.218^{* * *} \\
(1.158)\end{array}$ & $\begin{array}{c}2.669 \\
(1.827)\end{array}$ & $\begin{array}{c}3.485^{* *} \\
(1.682)\end{array}$ & $\begin{array}{c}3.801 \\
(2.724)\end{array}$ \\
\hline Savings\#Openness & $\begin{array}{c}-0.185^{* * *} \\
(0.0592)\end{array}$ & $\begin{array}{l}-0.107 \\
(0.101)\end{array}$ & $\begin{array}{c}-0.150 \\
(0.0917)\end{array}$ & $\begin{array}{c}-0.264^{* *} \\
(0.113)\end{array}$ \\
\hline ToT growth & $\begin{array}{l}-0.139 \\
(0.618)\end{array}$ & $\begin{array}{c}0.522 \\
(0.768)\end{array}$ & $\begin{array}{c}0.457 \\
(0.603)\end{array}$ & $\begin{array}{c}0.954 \\
(0.755)\end{array}$ \\
\hline Savings\#ToT & $\begin{array}{r}-0.0286^{*} \\
(0.0157)\end{array}$ & $\begin{array}{r}-0.0325^{*} \\
(0.0187)\end{array}$ & $\begin{array}{c}-0.0386^{* *} \\
(0.0163)\end{array}$ & $\begin{array}{c}-0.0429^{* *} \\
(0.0163)\end{array}$ \\
\hline Fixed-Effects & $\mathrm{N}$ & $\mathrm{N}$ & $\mathrm{Y}$ & $\mathrm{Y}$ \\
\hline Time-Effects & $\mathrm{Y}$ & $\mathrm{Y}$ & $\mathrm{Y}$ & $\mathrm{Y}$ \\
\hline Observations & 607 & 192 & 607 & 192 \\
\hline R-squared & 0.502 & 0.566 & 0.453 & 0.554 \\
\hline Number of id & & & 123 & 42 \\
\hline
\end{tabular}

Robust standard errors in parentheses. ${ }^{* * *} \mathrm{p}<0.01,{ }^{* *} \mathrm{p}<0.05,{ }^{*} \mathrm{p}<0.1$ 
Figure 8: Savings Investment Correlation across Time

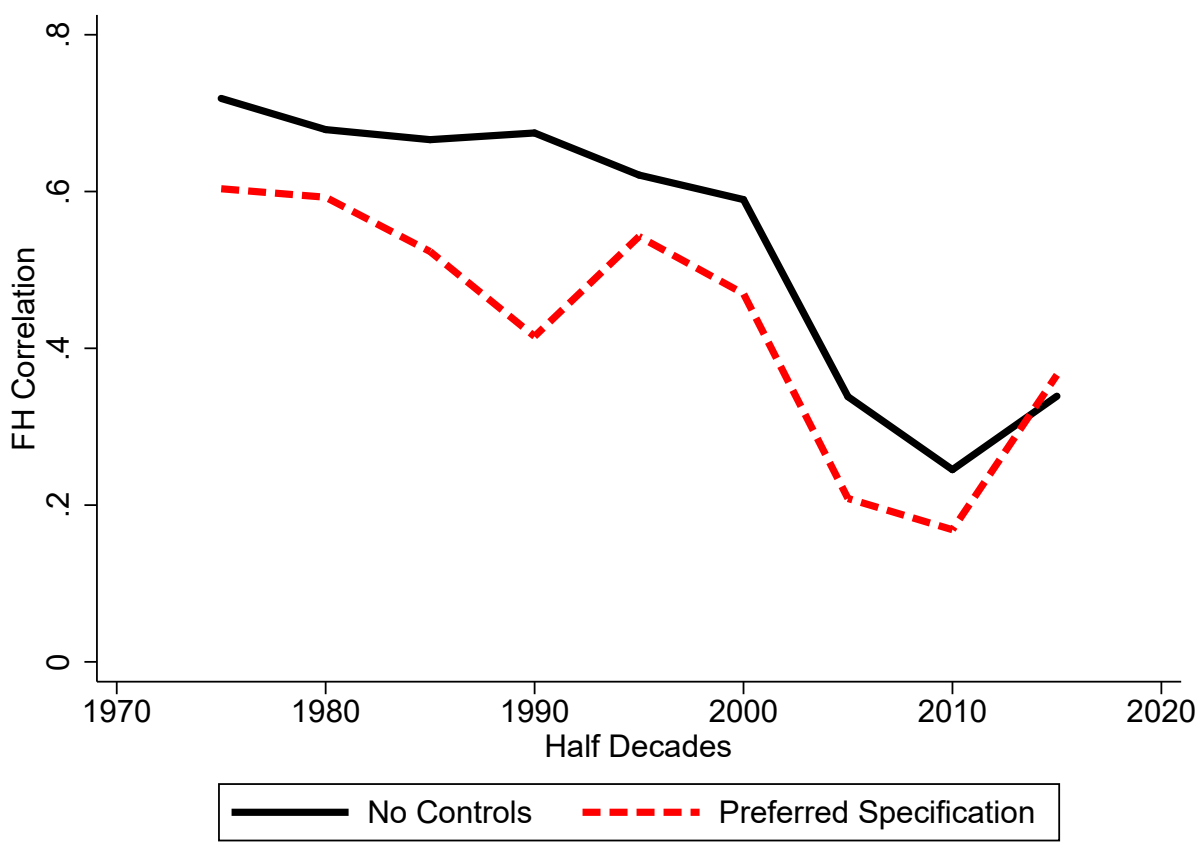

As a final robustness check, we run the benchmark models using data on private savings and investment rates from the WEO database. This comes, however, at a cost of significantly smaller samples. Table 5 presents the findings. The coefficients for the savings rate across the different specifications are somewhat lower than the ones presented in the benchmark regressions, but still statistically significant in most cases (note that the coefficient in the last regression for non-AE countries is marginally significant with a p-value of 0.10 ) with the exception of the specification focusing exclusively on AEs, which presents a coefficient that is not statistically significant at conventional levels.

\section{Assessing Causality with Instrumental Variables}

But is the relation between domestic savings and investment causal? Arguably, the assertion that domestic savings cause investment should not come as a big surprise given the pervasiveness of informational/enforcement problems related to capital crossing national borders. Home bias means that an exogenous increase in internal savings should indeed push domestic investment upwards, since the competing explanation is a 1 to 1 increase in the net foreign asset position of the country.

A number of papers have tried to address causality between savings and investment rates using Granger-causality tests in panel settings (for example Attanasio, Picci, and Scorcu, 2000; Irandoust, 2019). The evidence generally suggests that the null hypothesis 
Table 5: Private Investment/Savings

\begin{tabular}{|c|c|c|c|c|}
\hline Controls & $\begin{array}{c}(1) \\
\text { Pooled } \\
\text { Full } \\
\text { I/GDP }\end{array}$ & $\begin{array}{c}(2) \\
\text { FE } \\
\text { Full } \\
\text { I/GDP }\end{array}$ & $\begin{array}{c}(3) \\
\mathrm{FE} \\
\mathrm{AE} \\
\mathrm{I} / \mathrm{GDP}\end{array}$ & $\begin{array}{c}(4) \\
\text { FE } \\
\text { Non-AE } \\
\text { I/GDP }\end{array}$ \\
\hline Savings/GDP & $\begin{array}{c}0.400^{* * *} \\
(0.0502)\end{array}$ & $\begin{array}{c}0.226^{* *} \\
(0.108)\end{array}$ & $\begin{array}{c}0.0718 \\
(0.0709)\end{array}$ & $\begin{array}{c}0.230 \\
(0.138)\end{array}$ \\
\hline Constraints on Executive & $\begin{array}{c}0.785^{* * *} \\
(0.184)\end{array}$ & & & \\
\hline Initial GDP & $\begin{array}{l}-1.76 \mathrm{e}-05 \\
(2.10 \mathrm{e}-05)\end{array}$ & $\begin{array}{c}-0.000330^{* * *} \\
(9.98 \mathrm{e}-05)\end{array}$ & $\begin{array}{l}-6.19 \mathrm{e}-05 \\
(9.96 \mathrm{e}-05)\end{array}$ & $\begin{array}{l}-0.000390 \\
(0.000288)\end{array}$ \\
\hline Fixed Effects & $\mathrm{N}$ & $\mathrm{Y}$ & $\mathrm{Y}$ & $\mathrm{Y}$ \\
\hline Time-Effects & $\mathrm{Y}$ & $\mathrm{Y}$ & $\mathrm{Y}$ & $\mathrm{Y}$ \\
\hline Observations & 458 & 458 & 106 & 352 \\
\hline R-squared & 0.284 & 0.123 & 0.286 & 0.131 \\
\hline Number of id & & 106 & 22 & 84 \\
\hline
\end{tabular}

that savings Granger-cause investment typically cannot be rejected. Nevertheless, in our view Granger-causality is an unconvincing test if one is concerned with economic identification. It simply indicates that one of the variables tends to move before the other. In other words, even if (using yearly data) domestic savings precedes investment, that does not mean that savings are causing investment in an economic sense. A host of third variables may be moving both, with investment responding with some lag, for instance.

Hence we follow a different approach and assess causality by using instrumental variables techniques. Dooley, Frankel and Mathieson (1987) is the only paper we are aware of that uses an IV approach similar to ours. They also resort to population shares (albeit a different one) as an instrument for savings, but explore only the cross-section dimension using a much smaller set of countries.

To fix ideas, consider a model where $Y_{i}$ is the outcome variable of interest (the investment rate in our case), $X_{i}$ is a vector of potentially endogenous regressors (savings rate), $Z_{i}$ a vector of instruments and $W_{i}$ a vector of exogenous regressors (for details, see Andrews, Stock, and Sun, 2019). $\varepsilon_{i}$ and $V_{i}^{\prime}$ are error terms.

$$
\begin{gathered}
Y_{i}=X_{i}^{\prime} \beta+W_{i}^{\prime} \kappa+\varepsilon_{i} \\
X_{i}^{\prime}=Z_{i}^{\prime} \pi+W_{i}^{\prime} \gamma+V_{i}^{\prime}
\end{gathered}
$$

We are interested in obtaining an estimate of the structural parameter $\beta$ in equation (1), 
but $X_{i}$ is endogenous, hence $E\left(X^{\prime} \varepsilon\right) \neq 0$ and the estimates obtained from a simple OLS regression will be biased. It is also useful to consider the so-called reduced form equation, where we substitute for $X_{i}$ in equation (1) to obtain an equation linking the outcome variable and the instruments:

$$
Y_{i}=Z_{i}^{\prime} \delta+W_{i}^{\prime} \tau+U_{i}
$$

Note that $\delta=\pi \beta$ in equation (3), where $\pi$ is the coefficient linking the endogenous variables and the instruments (see equation (2), the first stage regression). The two-stage-least-squares estimator $\hat{\beta}_{T S L S}$ will be a function of $\hat{\delta}$ and $\hat{\pi}$, the OLS estimates of $\delta$ (the coefficient in the reduced form equation) and $\pi$ (the coefficient in the first stage regression). ${ }^{7} \hat{\beta}_{T S L S}$ will be consistent and asymptotically normally distributed, provided that instruments are strong $\left(E\left(Z^{\prime} X\right) \neq 0\right)$ and excludable $\left(E\left(Z^{\prime} \varepsilon\right)=0\right)$.

\subsection{Identification strategy}

The list of potential determinants of savings is vast and has been aptly surveyed by Grigoli, Herman, and Schmidt-Hebbel (2018). The problem is that to find appropriate instruments, we need variables that are strongly correlated with savings rates, but that are not correlated with other determinants of investment that are not controlled for in Equation (1). Demographic variables are found to be important determinants of savings (Cavallo, Sanchez, and Valenzuela, 2016) and, if chosen carefully, are not likely to affect investment via other channels. These are thus our candidates for instruments.

Specifically, we propose to use age structure as an instrument for the savings rate in line with the life-cycle hypothesis. Working-age adults are the typical savers in any economy, while the eldest dissave and the young tend to mostly consume. Arguably, middle-career adults should do the lion's share of the saving since income usually increases with years of experience and young adults are expected to smooth their consumption profiles.

We use the share of people in the [35:49] age bracket as an instrument for the savings rate. Interestingly, since this variable varies across countries and across time, we are able to run instrumental variable regressions exploring also the time dimension. Figure 9 indicates that population structure is positively related to the savings rate (as expected) in a statistically significant way. Not surprisingly, it is also related to invest rates (see the discussion below).

\footnotetext{
${ }^{7}$ More specifically, $\hat{\beta}_{T S L S}=\left(\hat{\pi}^{\prime} Q_{Z Z} \hat{\pi}\right)^{-1} \hat{\pi}^{\prime} Q_{Z Z} \hat{\delta}$, where $Q_{Z Z}=1 / n \sum Z_{i} Z_{i}^{\prime}$.
} 
Figure 9: Savings, Investment and Population Share across Countries and Time
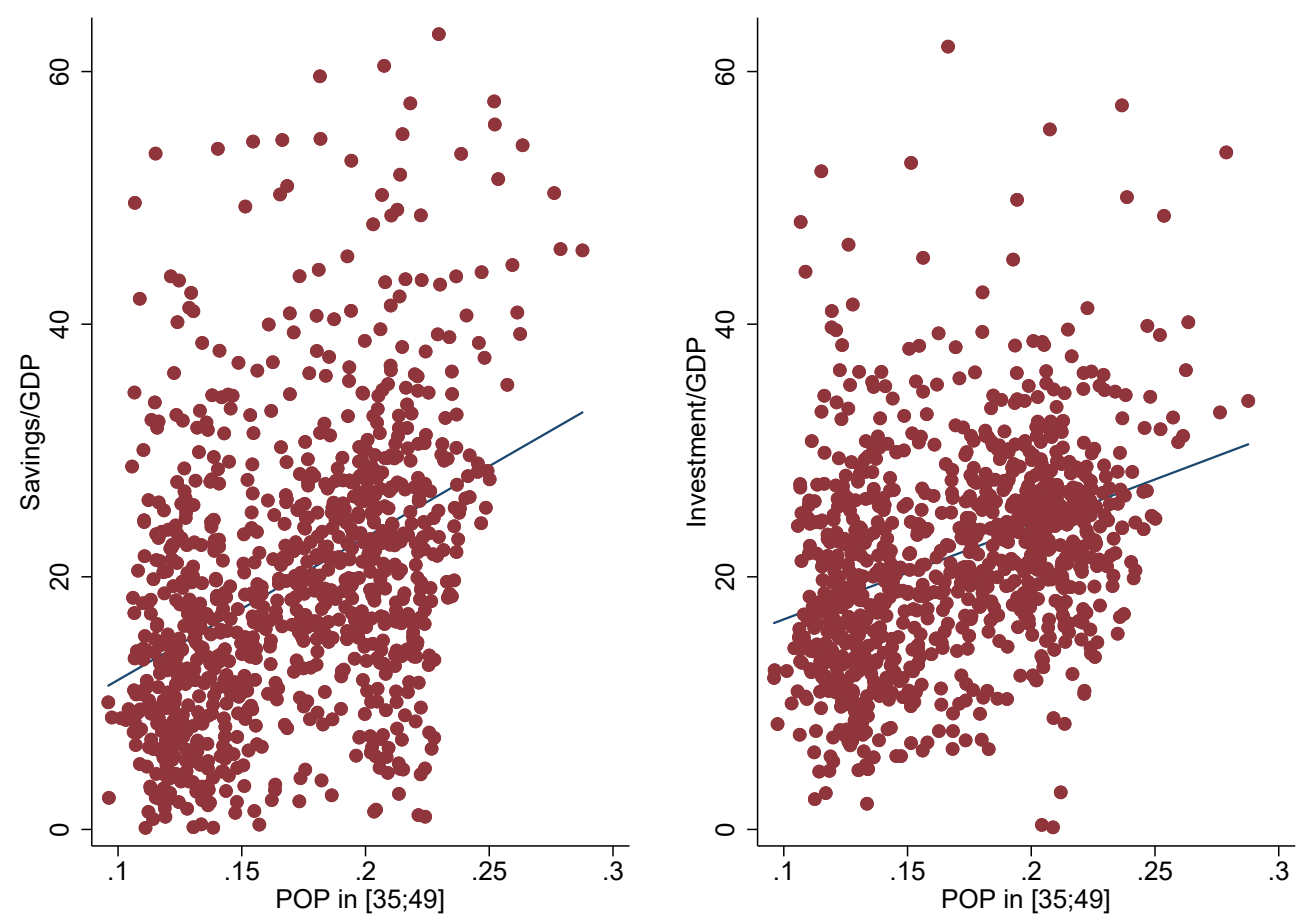

As previously discussed, $E\left(Z^{\prime} X\right) \neq 0$ is not a sufficient condition for a valid instrument. Excludability, that is, $E\left(Z^{\prime} \varepsilon\right)=0$ is also required as part of the identification strategy. Does the population share affect investment only though its effect on savings? Aksoy et al. (2019) present evidence that population age structure affects the rate of patent creation and hence innovation in advanced economies. But this is not incompatible with our exclusion restriction. Even if aging in rich countries hinders innovation and thus the expansion of the global technological frontier, it doesn't follow that aging in developing economies should affect investment. Developing economies typically are not pushing the technological frontier; they are trying to catch-up.

Another possible argument against our identification strategy goes along these lines: the higher the fraction of the population in the working-age bracket, the more firms would like to invest since capital, $K$, and labor, $L$, are complementary inputs in the production function. That is certainly true for a Hicks-neutral technology and homoegenous $K$. But firms do tailor investment and technological choices taking into account relative factor scarcity, as emphasized by the directed technological change literature (Acemoglu, 2015). If a certain factor becomes scarcer relative to others, technological investment will change "colors", not necessarily decrease altogether.

Arguably, as the working-age population shrinks, investment should target labor-saving 
technologies (Acemoglu and Restrepo, 2017) instead of simply falling. Further, the case for the exclusion restriction we use seems even stronger if one focuses on a very specific age bracket, as the share of adults in the [35:49]. Why would total capital investment depend on this specific sub-sample of the work force?

Furthermore, empirically, data patterns for the US lend credence to our exclusion restriction. Because of its "exorbitant privilege" in international credit markets, the US economy should be able to finance domestic investment unconstrained by the limits of its domestic savings, tapping into foreign sources to the extent needed. Since we know changes in age structure through time affect savings, but domestic savings do not matter for investment in the US, a reduced form correlation between age structure and investment in this case would cast serious doubts on our exclusion restriction. It would mean that age structure is per se relevant to overall investment. As Figure 10 suggests, however, data do not reveal any sort of reduced-form association between these two variables for the US economy over the 1975-2017 period.

Figure 10: Investment and Population Share in the US

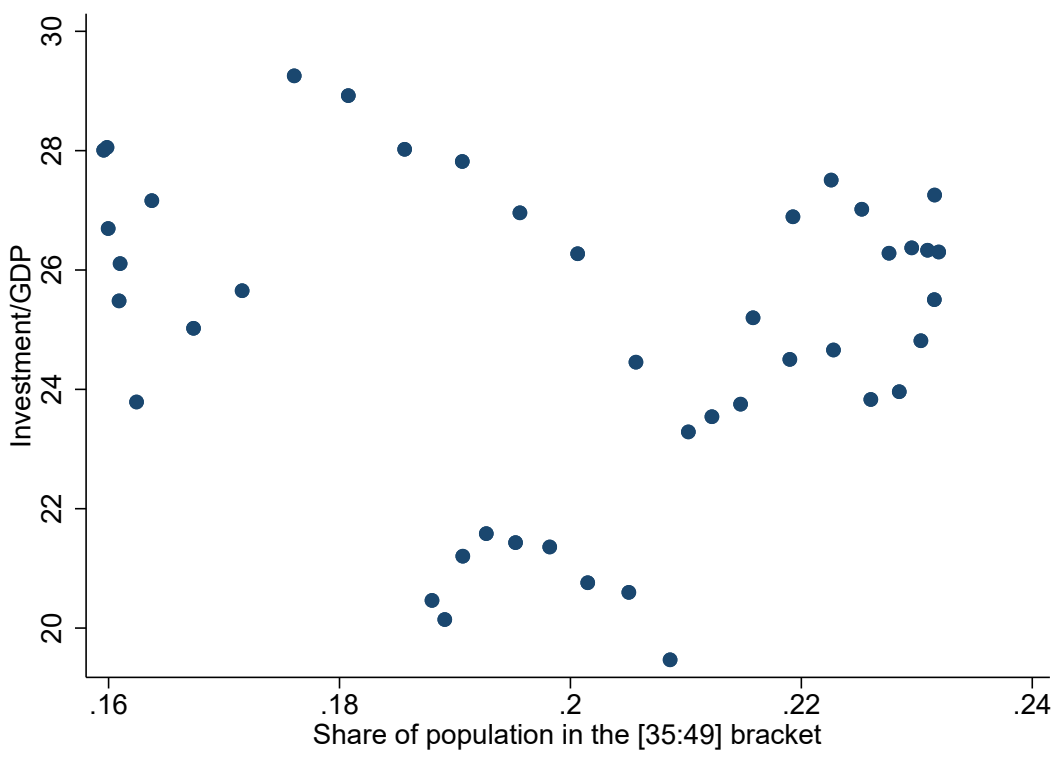

\subsection{Panel-IV results with one endogenous variable}

Table 6 presents the results for two-stage-least squares (IV) specifications as well as the comparable OLS results for reference. The IV models are exactly identified, that is, we have one instrument for the endogenous variable domestic savings rate. We can confirm the positive and statistically significant coefficient for the savings rate in the investment rate regressions. The IV estimates for the whole sample of countries and for the sample of 
emerging and developing economies are statistically significant, pointing to a causal relationship between domestic savings and investment. In fact, they are larger than their OLS counterparts, suggesting the presence of measurement error in the savings variable.

However, for the subset of 27 advanced economies the estimated coefficient drops to zero (statistically speaking) in the IV regression. These results contrast starkly with the findings of Dooley, Frankel and Mathieson (1987), who report higher OLS estimates for AEs and statistically insignificant IV results. The results of the IV regressions remain similar when we include the price of capital as an additional control variable (Table 7$).{ }^{8}$

Table 6: Panel 2SLS Estimates, dependent variable is investment/GDP

\begin{tabular}{|c|c|c|c|c|c|c|}
\hline Controls & $\begin{array}{c}(1) \\
\text { OLS - Full } \\
\text { I/GDP }\end{array}$ & $\begin{array}{c}\text { (2) } \\
\text { IV- Full } \\
\text { I/GDP }\end{array}$ & $\begin{array}{c}(3) \\
\text { OLS-Non-AE } \\
\text { I/GDP }\end{array}$ & $\begin{array}{c}\text { (4) } \\
\text { IV-Non-AE } \\
\text { I/GDP }\end{array}$ & $\begin{array}{c}5) \\
\text { OLS-AE } \\
\text { I/GDP }\end{array}$ & $\begin{array}{c}6) \\
\text { IV-AE } \\
\text { I/GDP }\end{array}$ \\
\hline Savings/GDP & $\begin{array}{c}0.417^{* * *} \\
(0.0530)\end{array}$ & $\begin{array}{c}0.540^{* * *} \\
(0.166)\end{array}$ & $\begin{array}{c}0.430 * * * \\
(0.0601)\end{array}$ & $\begin{array}{c}0.687^{* * *} \\
(0.184)\end{array}$ & $\begin{array}{c}0.287^{* *} \\
(0.116)\end{array}$ & $\begin{array}{l}-0.135 \\
(0.445)\end{array}$ \\
\hline Initial GDP & $\begin{array}{c}-0.000357^{* * * *} \\
(6.81 \mathrm{e}-05) \\
\end{array}$ & $\begin{array}{c}-0.000348^{* * *} \\
(5.18 \mathrm{e}-05) \\
\end{array}$ & $\begin{array}{c}-2.13 \mathrm{e}-05 \\
(0.000110) \\
\end{array}$ & $\begin{array}{c}1.40 \mathrm{e}-05 \\
(0.000168) \\
\end{array}$ & $\begin{array}{c}-0.000338^{* * *} \\
(0.000102) \\
\end{array}$ & $\begin{array}{c}-7.44 \mathrm{e}-05 \\
(0.000230) \\
\end{array}$ \\
\hline Time-effects & $\mathrm{Y}$ & $\mathrm{Y}$ & $\mathrm{Y}$ & $\mathrm{Y}$ & $\mathrm{Y}$ & $\mathrm{Y}$ \\
\hline Fixed-effects & $\mathrm{Y}$ & $\mathrm{Y}$ & $\mathrm{Y}$ & $\mathrm{Y}$ & $\mathrm{Y}$ & $\mathrm{Y}$ \\
\hline Observations & 916 & 789 & 693 & 590 & 223 & 199 \\
\hline Number of id & 136 & 125 & 108 & 98 & 28 & 27 \\
\hline R-squared & 0.270 & 0.274 & 0.282 & 0.242 & 0.361 & 0.136 \\
\hline K-P F-stat & & 19.46 & & 16.82 & & 4.80 \\
\hline Effective F-stat & & 6.40 & & 6.27 & & 1.43 \\
\hline
\end{tabular}

Moreover, we also estimated specifications reported in Appendix $\mathrm{C}$ that add an additional instrument to tackle endogeneity in the price of capital. We follow Lian et al. (2019) and use the average relative price in all other countries except the countrys own as an instrument. This approach isolates technologically driven changes in the relative price from those that may occur due to changes in demand for investment goods within a country, reducing the measurement error bias. The savings rate coefficient results are similar to the ones reported in Table 7 , but there is evidence of weak instruments and the coefficient of the control variable is not significant.

As we have discussed previously, conventional instrumental variable methods for estimation and inference become unreliable if instruments are weak. There is some evidence that weak instruments are an issue in the regressions reported in Table 6. The Montiel Olea

\footnotetext{
${ }^{8}$ We also estimated regressions with the capital account openness index as a control, but that variable does not enter significantly in the specifications.
} 
Table 7: Panel 2SLS Estimates, dependent variable is investment/GDP

\begin{tabular}{|c|c|c|c|}
\hline Controls & $\begin{array}{c}\text { (1) } \\
\text { IV- Full } \\
\text { I/GDP }\end{array}$ & $\begin{array}{c}(2) \\
\text { IV-Non-AE } \\
\text { I/GDP }\end{array}$ & $\begin{array}{c}(3) \\
\mathrm{IV}-\mathrm{AE} \\
\mathrm{I} / \mathrm{GDP}\end{array}$ \\
\hline Savings/GDP & $\begin{array}{c}0.568^{* * *} \\
(0.161)\end{array}$ & $\begin{array}{c}0.721^{* * * *} \\
(0.180)\end{array}$ & $\begin{array}{l}-0.177 \\
(0.433)\end{array}$ \\
\hline Initial GDP & $\begin{array}{c}-0.000348^{* * *} \\
(5.21 \mathrm{e}-05)\end{array}$ & $\begin{array}{c}-2.37 \mathrm{e}-05 \\
(0.000168)\end{array}$ & $\begin{array}{c}2.34 \mathrm{e}-05 \\
(0.000254)\end{array}$ \\
\hline Inv. Price & $\begin{array}{c}-0.215^{* * *} \\
(0.0666)\end{array}$ & $\begin{array}{l}-0.183^{* *} \\
(0.0709)\end{array}$ & $\begin{array}{c}-22.73^{* * *} \\
(8.230)\end{array}$ \\
\hline Time-effects & $\mathrm{Y}$ & $\mathrm{Y}$ & $\mathrm{Y}$ \\
\hline Fixed-effects & $\mathrm{Y}$ & $\mathrm{Y}$ & $\mathrm{Y}$ \\
\hline Observations & 789 & 590 & 199 \\
\hline Number of id & 125 & 98 & 27 \\
\hline R-squared & 0.283 & 0.234 & 0.300 \\
\hline K-P F-stat & 20.35 & 17.68 & 5.626 \\
\hline Effective F-stat & 6.69 & 6.61 & 1.77 \\
\hline
\end{tabular}

and Pueger (2013) effective F-statistics are below their respective critical values in all specifications. ${ }^{9}$ Nevertheless, for the Kleinbergen-Paap rk Wald F statistic, the critical values are exceed in all IV specifications except for the one focusing on AEs (we consider a critical value of 16.38 following Stock and Yogo, 2005).

Therefore, in Figure 11, we report the Anderson-Rubin (AR) weak instruments robust confidence intervals for the parameter of interest (see Bazzi and Clemens, 2013 and Andrews, Stock, and Sun, 2019 for a practical discussion of inference under weak instruments). In all cases the coefficient on the savings rate passes the weak-instrument-robust statistical significance test at the 5 percent level i.e. the coefficients on the national savings rate are different from zero for the full sample and for the sample of non-AEs.

\subsection{Cross-sectional IV with two endogenous variables}

In this section we estimate IV models on averaged cross-sections so that it becomes possible to include the slow-moving "controls of the executive" variable aiming to capture expropriation risk. Expropriation risk, however, is likely to be itself endogenous to investment

\footnotetext{
${ }^{9}$ We consider a value for the weak instrument threshold of $\tau=10 \%$ for the Montiel Olea and Pflueger test i.e. the null hypothesis is that the IV asymptotic bias exceeds 10 percent of the OLS bias. The critical value in this case is 23.11 .
} 
Figure 11: Weak Instruments Robust Confidence Intervals
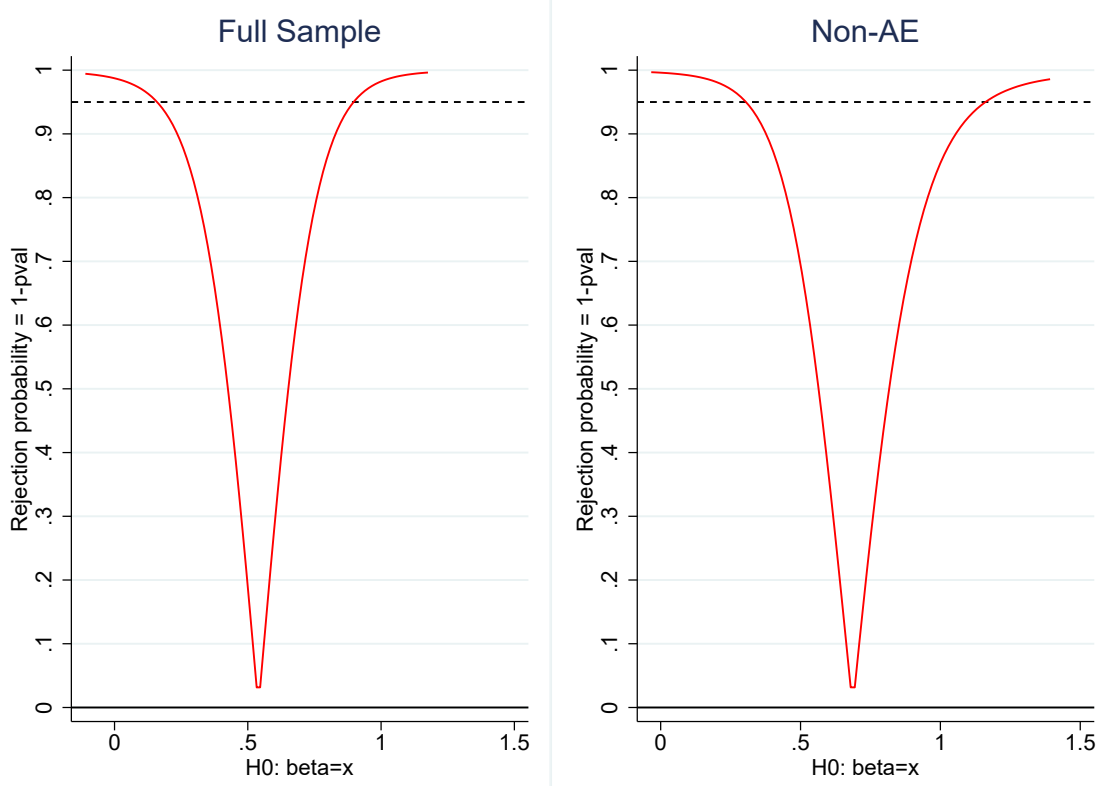

rates in addition to being a slow moving variable. In most of the previous section, we only considered the endogeneity of the savings rate. Here we expand the instruments set to tackle the endogeneity of expropriation risk as well.

To that end, we resort to colonial origins indicators as instruments, more specifically we use a country's latitude, it's aboriginal population density and settler mortality as proxies for colonial origins. The rationale for using colonial origins as an instrument for expropriation risk was spelled out in Acemoglu, Johnson, and Robinson (2001). In a nutshell, these authors argue that these factors affects the quality of nascent institutions and these in turn, through institutional-stickiness, affect the quality of current institutions. Since these historical instruments present no time variation, we collapse the time dimension and examine to what extent the exogenous part of our two endogenous variables (namely the savings rate and expropriation risk) are relevant to explain average investment.

In Table 8 we present the OLS model as well as three different IV models. In the first IV regression (IV1) we just include latitude as an instrument for expropriation risk (so that the model is exactly identified). Subsequently, we add aboriginal population density (IV2) and settler mortality as additional instruments (IV3). All IV regressions instrument the savings rate with our population structure variable.

The results show that domestic savings continue to matter for investment and the savings coefficient varies little across specifications. Once again, this suggests that the bare- 
Table 8: Cross-sectional 2SLS Estimates, Full Sample

\begin{tabular}{lcccc}
\hline & $(1)$ & $(2)$ & $(3)$ & $(4)$ \\
Controls & OLS & IV1 & IV2 & IV3 \\
& I/GDP & I/GDP & I/GDP & I/GDP \\
\hline \multirow{3}{*}{ S/GDP } & $0.399^{* * *}$ & $0.623^{* * *}$ & $0.629^{* * *}$ & $0.585^{* * *}$ \\
& $(0.0665)$ & $(0.173)$ & $(0.154)$ & $(0.0804)$ \\
Constraints on Executive & $0.514^{*}$ & 0.242 & 0.278 & 0.410 \\
& $(0.278)$ & $(1.067)$ & $(0.955)$ & $(0.980)$ \\
Initial GDP & $1.46 \mathrm{e}-05$ & $-8.32 \mathrm{e}-05$ & $-9.05 \mathrm{e}-05$ & $-2.85 \mathrm{e}-05$ \\
& $(5.08 \mathrm{e}-05)$ & $(0.000131)$ & $(0.000135)$ & $(0.000112)$ \\
\hline Kleibergen-Paap F-stat & & 1.93 & 2.58 & 6.58 \\
F-stat (Critical Values) & & 7.03 & 13.43 & 7.56 \\
J-stat (p-value) & 119 & 113 & 0.93 & 0.66 \\
Observations & 0.517 & 0.379 & 0.377 & 0.486 \\
R-squared & \multicolumn{4}{c}{112} \\
\hline \multicolumn{2}{c}{ Robust standard errors in parentheses. ${ }^{* * *} \mathrm{p}<0.01, * * \mathrm{p}<0.05, * \mathrm{p}<0.1$}
\end{tabular}

bones neoclassical model story is inaccurate. Constraints on the Executive are positive, but not statistically significant in the IV models. It is important to note that this is due to a steep rise in the standard-errors of the coefficients. For the overidentified models (where the number of instruments exceeds the number of endogenous variables), the Hansen-J statistic points to the validity of the instruments set.

Once again, the Kleinbergen-Paap F-statistics clearly indicate that instruments are weak. Therefore, we also present two-dimensional weak instruments robust confidence sets and rejection surface for the two coefficients of interest (Figure 12). The AR test has a p-value of 0.04 , the null being both coefficients of interest are equal to 0. Figure 12 shows that the coefficient linking savings to investment is always above the 0 threshold, even if the same cannot be said about the Control of the Executive variable. 
Figure 12: Weak Instruments Robust Confidence Sets

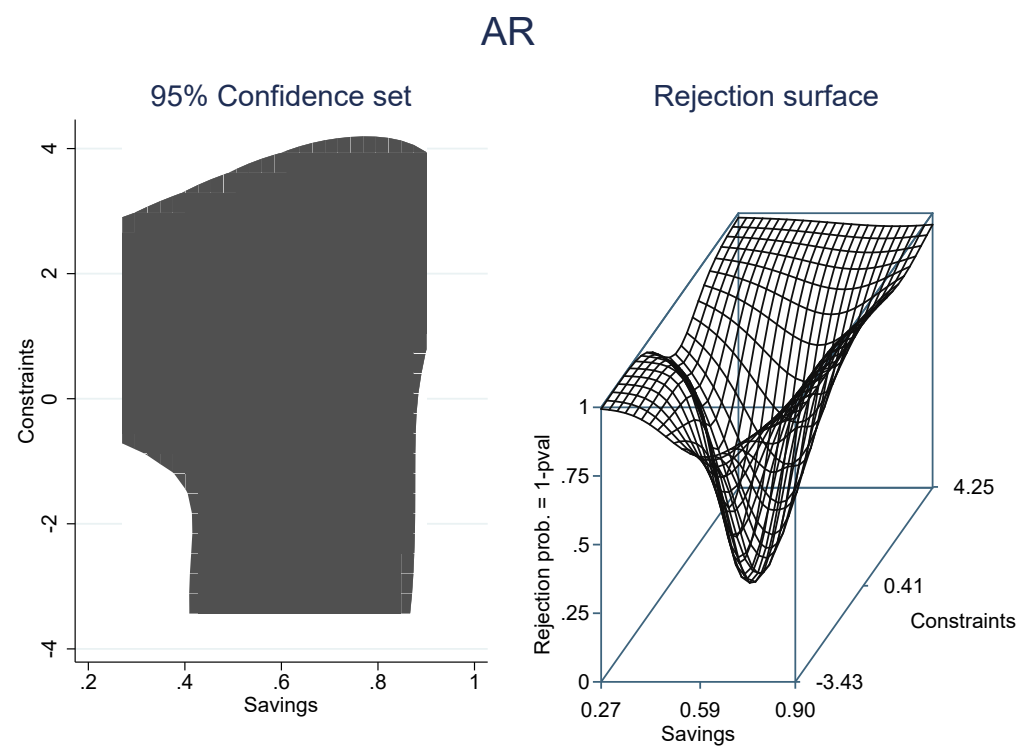

\section{Conclusions}

In this paper we revisited the FH puzzle and showed that even though the savings and investment correlation holds across time and groups of countries, it also varies across those dimensions. Using two types of instrumental variables approaches, we conclude that the relationship is causal, with variations in domestic savings causing variations in investment. In fact, instrumental variables point estimates are larger than their OLS counterparts, suggesting the presence of measurement error in domestic savings.

However, for the subset of 27 advanced economies, the estimated coefficient for the domestic savings rate is not statistically significant, indicating that the observed FH correlation in advanced economies is likely to be a result of endogeneity bias. Overall, these results contrast with earlier findings by Dooley, Frankel and Mathieson (1987), which consider a smaller sample of countries, different set of instruments for savings, and only presented cross-sectional results.

The findings presented in the paper imply that low national savings are likely to constrain investment, even if a country is open to international capital flows. To alleviate this constraint, policymakers could consider interventions to promote domestic savings and to increase the amount of national savings intermediated through the financial system. One avenue to achieve this goal might be policies that foster competition and help reduce the costs of provision of financial services. 


\section{References}

Acemoglu, D., Johnson, S., and Robinson, J. A., 2001. "The Colonial Origins of Comparative Development: An Empirical Investigation." American Economic Review 91: 1369-1401.

Acemoglu, D., 2015. "Localized and Biased Technologies: Atkinson and Stiglitz's New View, Induced Innovations, and Directed Technological Change." Economic Journal 125: 443-463.

Acemoglu, D., and Restrepo, P., 2017. "Secular Stagnation? The Effect of Aging on Economic Growth in the Age of Automation." American Economic Review 107: 174-179.

Aksoy, Y., Basso, H., Smith, R. P., and Grasil, T., 2019 "Demographic Structure and Macroeconomic Trends" American Economic Journal: Macroeconomics 11: 193-222.

Andrews, I., Stock, J., and Sun, L., 2019. "Weak Instruments in IV Regression: Theory and Practice" Annual Review of Economics, Forthcoming.

Aspergis, N. and Tsoumas, C., 2009. "A Survey of the Feldstein-Horioka Puzzle: What has been Done and Where We Stand." Research in Economics 63: 64-76.

Attanasio, O., Picci, L., and Scorcu, A. E., 2000. "Saving, Growth, and Investment: A Macroeconomic Analysis Using a Panel of Countries" Review of Economics and Statistics 82: $182-211$.

Bai, Y. and Zhang, J., 2010. "Solving the Feldstein-Horioka Puzzle with Financial Frictions." Econometrica 78: 603-632.

Barro, R., Mankiw, N. G., Sala-i-Martin, X., 1995. "Capital Mobility in Neoclassical Models of Growth" American Economic Review 85: 103-115.

Baxter, M. and Crucini, M. J., 1993. "Explaining Saving-Investment Correlations" American Economic Review 83: 416-436.

Bazzi, S. and Clemens, M., 2013. "Blunt Instruments: Avoiding Common Pitfalls in Identifying the Causes of Economic Growth." American Economic Journal: Macroeconomics 5: 152-186.

Benhabib, J., and Spiegel, M., 2000. "The Role of Financial Development in Growth and Investment." Journal of Economic Growth 5: 341-306.

Cavallo, E. and Pedemonte, M., 2015. "What is the Relationship between National Saving and Investment in Latin America and the Caribbean?" IDB Working Paper IDB-WP-617 (Washington: Interamerican Development Bank). 
Cavallo, E., Sanchez, G., and Valenzuela, P., 2016. "Gone with the Wind: Demographic Transitions and Domestic Saving." IDB Working Paper IDB-WP-688 (Washington: Interamerican Development Bank).

Chinn, M. D., and Ito, H., 2006. "What Matters for Financial Development? Capital Controls, Institutions, and Interactions". Journal of Development Economics, 81: 163-192.

Coeurdacier, N., Guibaud, S. and Jin, K., 2015. "Credit Constraints and Growth in a Global Economy". American Economic Review, 105: 2838-2881.

Dooley, M., Frankel, J. and Mathieson, D. J., 1987. "What Do Saving-Investment Correlations Tell Us?" IMF Staff Papers, 34: 503-530.

Feenstra, R. C., Inklaar, R. and Timmer, M. P., 2015. "The Next Generation of the Penn World Table." American Economic Review 105: 3150-3182.

Feldstein, M. S. and Horioka, C. Y., 1980. "Domestic Saving and International Capital Flows" Economic Journal 90: 314-329.

Glick, R. and Rogoff, K., 1995. "Global versus Country-Specific Productivity Shocks and the Current Account." Journal of Monetary Economics 35: 159-132.

Grigoli, F., Herman, A., and Schmidt-Hebbel, K. 2018. "Saving in the World" World Development 104: 257-270.

Gruss, B., 2014. "After the Boom: Commodity Prices and Economic Growth in Latin America and the Caribbean". IMF Working Paper 14/154. (Washington: International Monetary Fund).

Horioka, C. Y. and Terada-Hagiwara, A., 2011. "The Determinants and Long-term Projections of Saving Rates in Developing Asia" NBER Working Paper 17581 (Cambridge: National Bureau of Economic Research).

Irandoust, M., 2019 "Saving and Investment Causality: Implications for Financial Integration in Transition Countries of Eastern Europe." International Econ Policy 16: 397-416.

Laeven, L. and Valencia, F., 2018. "Systemic Banking Crises Revisited" IMF Working Paper No. 18/206 (Washington: International Monetary Fund).

Lian, W., Novta, N., Pugacheva, E., Timmer, Y., and Topalova, P., 2019. "The Price of Capital Goods: A Driver of Investment Under Threat?" IMF Working Paper No. 19/134 (Washington: International Monetary Fund). 
Marshall, M., G., Gurr, R., and Jaggers, K., 2019. "Polity IV Project Political Regime Characteristics and Transitions, 1800-2018" Center for Systemic Peace.

Montiel Olea, J. L., and Pflueger, C. E., 2013. "A Robust Test for Weak Instruments" Journal of Business and Economic Statistics 31: 358-369.

Obstfeld, M. and Rogoff, K., 2000. "The Six Major Puzzles in International Macroeconomics: Is There a Common Cause?" NBER Working Paper 7777 (Cambridge: National Bureau of Economic Research).

Singh, T., 2016. "Rhetorics of savings-investment correlations and the international mobility of capital: A survey" Journal of International Trade and Economic Development 25: 639-690.

Stock, J. H. and Yogo, M., 2005. "Testing for Weak Instruments in Linear IV Regression" in Identification and Inference for Econometric Models: Essays in Honor of Thomas Rothenberg, Eds. D.W.K. Andrews and J.H. Stock, 80-108. New York: Cambridge University Press.

Svirydzenka, K., 2016. "Introducing a New Broad-based Index of Financial Development". IMF Working Paper 16/5 (Washington: International Monetary Fund). 


\section{A Appendix: Data Sources and Definitions}

Investment and National Savings Rates. National savings and investment rates (capital formation) are available directly from the WEO and WDI datasets. Both variables are expressed as a share of GDP. The WEO database also contains information on private savings and investment rates. We also use the share of gross capital formation in current PPP terms from Feenstra, Inklaar, and Timmer (2015). For PWT 9.1 data, the savings rate is calcualted as $1-c s h_{c}-c s h_{g}$, where $c s h_{c}$ is the share of share of household consumption in current PPP terms and $c s h_{g}$ is the share of government consumption in current PPP terms.

GDP per Capita. GDP per capita in real PPP terms compiled by Feenstra, Inklaar, and Timmer (2015). 2011 is the base year.

Property Rights. Constraints on the power of the executive variable (xconst) from the Polity IV project (Marshall, Gurr, and Jaggers, 2019), which aims to capture checks and balances between the various parts of the decision-making process. A seven-category scale is used ranging from 1 (Unlimited authority) to 7 (Executive parity or subordination).

Relative Price of Capital. This is constructed as the ratio of $p l_{i} / p l_{c}$ in PWT 9.1 (Feenstra, Inklaar, and Timmer, 2015) i..e the ratio of the price level of capital formation to the price level of household consumption both expressed relative to the price level of US GDP in 2011.

Capital account restrictions. Index of de jure capital account openness constructed by Chinn and Ito (2006) based on information from the IMF's Annual Report on Exchange Arrangements and Exchange Restrictions (AREAER). Higher levels of the index indicate a more open capital account.

Demographic Structure. We consider two alternative measures: the share of the population in the [35:49] age bracket and the share of the population in the [15:64] age bracket. Both variables come from the World Bank's WDI database.

Terms of trade. Commodity net export price index constructed by Gruss (2014).

Crises Dates. Dummy variable taking the value of one is a banking crisis and/or currency crisis and/or sovereign debt crisis occurred in a given year based on Laeven and Valencia (2018). 


\section{B Appendix: Country Classification}

\begin{tabular}{|c|c|c|c|c|c|}
\hline \multirow{2}{*}{$\begin{array}{c}\text { Advanced } \\
\text { AUS }\end{array}$} & \multicolumn{3}{|c|}{ Emerging Markets } & \multicolumn{2}{|c|}{ Low Income } \\
\hline & AGO & GNQ & PAN & BDI & SWZ \\
\hline AUT & ALB & GTM & PER & BEN & TCD \\
\hline BEL & ARE & HND & PHL & BFA & TGO \\
\hline CAN & ARG & HRV & POL & BGD & TZA \\
\hline CHE & ARM & HUN & PRY & BTN & UGA \\
\hline CZE & AZE & IDN & QAT & CAF & YEM \\
\hline DEU & BGR & IND & ROU & CIV & ZMB \\
\hline DNK & BHR & IRN & RUS & CMR & ZWE \\
\hline ESP & BLR & IRQ & SAU & ETH & \\
\hline FIN & BOL & JAM & SLV & GIN & \\
\hline FRA & BRA & JOR & SRB & GMB & \\
\hline GBR & BWA & KAZ & SYR & HTI & \\
\hline GRC & CHL & KWT & THA & KEN & \\
\hline IRL & $\mathrm{CHN}$ & LAO & TKM & KGZ & \\
\hline ISR & COD & LBN & TTO & KHM & \\
\hline ITA & $\mathrm{COG}$ & LTU & TUN & LBR & \\
\hline JPN & $\mathrm{COL}$ & LVA & TUR & LKA & \\
\hline KOR & CPV & MAR & TWN & LSO & \\
\hline LUX & CRI & MDG & UKR & MDA & \\
\hline NLD & CYP & MEX & URY & MLI & \\
\hline NOR & DJI & MKD & UZB & $\mathrm{MOZ}$ & \\
\hline NZL & DOM & MMR & VEN & MRT & \\
\hline PRT & DZA & MNE & VNM & MWI & \\
\hline SGP & ECU & MNG & ZAF & NER & \\
\hline SVK & EGY & MUS & & NGA & \\
\hline SVN & EST & MYS & & NPL & \\
\hline SWE & FJI & NAM & & RWA & \\
\hline \multirow[t]{3}{*}{ USA } & GAB & NIC & & SDN & \\
\hline & GEO & OMN & & SEN & \\
\hline & GHA & PAK & & SUR & \\
\hline
\end{tabular}




\section{Appendix: Additional Regressions}

Table 9: Regressions Adding Financial Development as a Control

\begin{tabular}{lcccc}
\hline & $(1)$ & $(2)$ & $(3)$ & $(4)$ \\
& Pooled & FE & FE & FE \\
Full & Full & AE & Non-AE \\
& I/GDP & I/GDP & I/GDP & I/GDP \\
\hline \multirow{2}{*}{ Savings/GDP } & & & & \\
& $0.408^{* * *}$ & $0.494^{* * *}$ & $0.338^{* * *}$ & $0.475^{* * *}$ \\
Constraints on Executive & $(0.0335)$ & $(0.0484)$ & $(0.0787)$ & $(0.0596)$ \\
& $0.465^{* * *}$ & & & \\
Initial GDP & $(0.133)$ & & & \\
& $-0.000121^{* *}$ & $-0.000481^{* * *}$ & $-0.000251^{* *}$ & -0.000214 \\
Inv. Price & $(4.69 \mathrm{e}-05)$ & $(5.51 \mathrm{e}-05)$ & $(0.000117)$ & $(0.000162)$ \\
& $-0.404^{* * *}$ & $-0.249^{* * *}$ & $-13.71^{* *}$ & $-0.236^{* * *}$ \\
Crises & $(0.154)$ & $(0.0353)$ & $(5.039)$ & $(0.0314)$ \\
Financial Development & $-2.095^{* * *}$ & & & \\
& $(0.548)$ & & & \\
Capital Openness & $9.045^{* * *}$ & 2.607 & $13.14^{* *}$ & 4.169 \\
& $(2.405)$ & $(3.818)$ & $(5.645)$ & $(6.418)$ \\
& & 1.365 & 0.286 & 1.557 \\
& & $(0.943)$ & $(1.191)$ & $(1.274)$ \\
Fixed-Effects & $\mathrm{N}$ & $\mathrm{Y}$ & $\mathrm{Y}$ & $\mathrm{Y}$ \\
Time-Effects & $\mathrm{Y}$ & $\mathrm{Y}$ & $\mathrm{Y}$ & $\mathrm{Y}$ \\
\hline Observations & 722 & 581 & 153 & 428 \\
R-squared & 0.501 & 0.486 & 0.436 & 0.533 \\
Number of id & & 118 & 27 & 91 \\
\hline & & &
\end{tabular}

Robust standard errors in parentheses

$$
\text { *** } \mathrm{p}<0.01,{ }^{* *} \mathrm{p}<0.05,{ }^{*} \mathrm{p}<0.1
$$


Table 10: Panel 2SLS Regressions Instrumenting for Savings and Investment Price

\begin{tabular}{lccc}
\hline & $(1)$ & $(2)$ & $(3)$ \\
& IV- Full & IV-Non-AE & IV-AE \\
Controls & I/GDP & I/GDP & I/GDP \\
\hline \multirow{3}{*}{ Savings/GDP } & $0.526^{* * *}$ & $0.610^{* * *}$ & -0.159 \\
& $(0.165)$ & $(0.190)$ & $(0.437)$ \\
Inv. Price & 0.107 & 0.415 & -13.44 \\
& $(0.385)$ & $(0.493)$ & $(9.467)$ \\
Initial GDP & $-0.000347^{* * *}$ & $9.97 \mathrm{e}-05$ & $-1.66 \mathrm{e}-05$ \\
& $(5.16 \mathrm{e}-05)$ & $(0.000178)$ & $(0.000249)$ \\
& & & \\
\hline Fixed-Effects & $\mathrm{Y}$ & $\mathrm{Y}$ & $\mathrm{Y}$ \\
Time-Effects & $\mathrm{Y}$ & $\mathrm{Y}$ & $\mathrm{Y}$ \\
\hline Observations & 789 & 590 & 199 \\
R-squared & 0.256 & 0.137 & 0.280 \\
Number of id & 125 & 98 & 27 \\
K-P F-stat & 1.343 & 1.712 & 2.665 \\
\hline
\end{tabular}

Robust standard errors in parentheses $* * * \mathrm{p}<0.01,{ }^{*} * \mathrm{p}<0.05,{ }^{*} \mathrm{p}<0.1$ 